\title{
Toward a sociology of finitude: life, death, and the question of limits
}

\author{
Roi Livne ${ }^{1}$
}

Accepted: 4 May 2021/Published online: 15 May 2021

(C) The Author(s), under exclusive licence to Springer Nature B.V. 2021

\begin{abstract}
Progressing beyond the given has been a key modern tendency. Yet modern societies are currently facing the problem of how to put limits on progress, expansion, and growth, live within them, and preserve (rather than transcend) the present. Drawing on economic sociology scholarship on valuation and morality in economic life, this article develops and applies the term economization to analyze the enactment of limits on progress. The question of end-of-life care - when to stop medical efforts to prolong life, postpone death, and advance the scientific frontier - serves as an illustrative empirical case that sheds light on limit-setting in general. My analysis of this case combines historical, ethnographic, and in-depth interview data on US palliative care clinicians, who specialize in making life-and-death decisions in acute care hospitals.
\end{abstract}

Keywords Economization $\cdot$ Economy $\cdot$ Expertise $\cdot$ Morality $\cdot$ Subjectivity $\cdot$ Valuation

\section{Progress and limits}

Progress, growth, and advent, which have been among modernity's most defining tendencies, are being called into question. This undermines some of the most central organizing principles of modern societies. Modernist thinkers characterized their times as a radical liberation from traditional authorities and the state of nature - a dynamism that unleashed an inherent human propensity to transcend the present (Kant, 1996; Marx, 1964, pp. 112-114). Being and acting human meant progressing beyond the given - surpassing nature, achieving control over it, and appropriating it for human needs (Kojève, 1969, pp. 24-25). It is human nature, Hegel wrote, to constitute "an antithesis to the natural world" (Hegel, 1997, p. 46), and therefore acting on this nature meant "a rebellion against human existence as it has been given" (Arendt, 1958, p. 2). This commitment to progress has been proto-religious; progress gives meaning to all

Roi Livne

rlivne@umich.edu

1 Department of Sociology, University of Michigan, Ann Arbor, MI, USA 
human pursuits and experiences, to the point that rejecting it is "tantamount to sacrilege" (Durkheim, 1995, p. 215).

Perhaps the strongest representations of progress and the modernist commitment to transcending nature are graphs of historical demographic and economic trends (Figs. 1 and 2), which demonstrate a major fault-line. For long millennia, from prehistory until the eighteenth century, the sizes of the human population and economy were relatively stable and the curves representing their growth were virtually flat. Humans lived, so to speak, within the boundaries that nature had set for them. Come the great modern revolutions - industrial, scientific, and political - development replaced stasis and the curves spiked, reaching unprecedented levels. These spikes visualize the boundlessness of the modern promise, which still echoes as the ethos of our time.

Of course, not all have glorified progress unequivocally. Bemoaning progress's risks and pitfalls has perhaps been as common as celebrating its potential (Slaboch, 2017). The social and political maladies of industrialization, urbanization, and the massification of society have fed volumes of sociological research since the discipline's very beginning. This dialectics of modernity reverberated through classical sociologists' magna opera (Durkheim, 1984; Marx, 1976, Chapter 10; Weber, 2011, pp. 177178) and post-WWII political theory. The Cold War introduced even greater existential fears: "there is no reason to doubt our present ability to destroy all organic life on Earth," Arendt wrote. "The question is only whether we wish to use our new scientific and technical knowledge in this direction" (Arendt, 1958, pp. 2-3). An amalgam of great hopes, tragedies, promises, and calamities, modernity appeared as a Faustian bargain, whose payment day was fast approaching (Berman, 1988).

This article, however, is less concerned with warnings about progress's potential risks and pitfalls, and more with discussions of its finitude and ultimate limits. Such discussions are not entirely new. From their remotely different perspectives, Thomas Malthus and Karl Marx both presented limits as endemic to modernity's progressive trajectory: Malthus warned of a misalignment between productivity's arithmetic growth

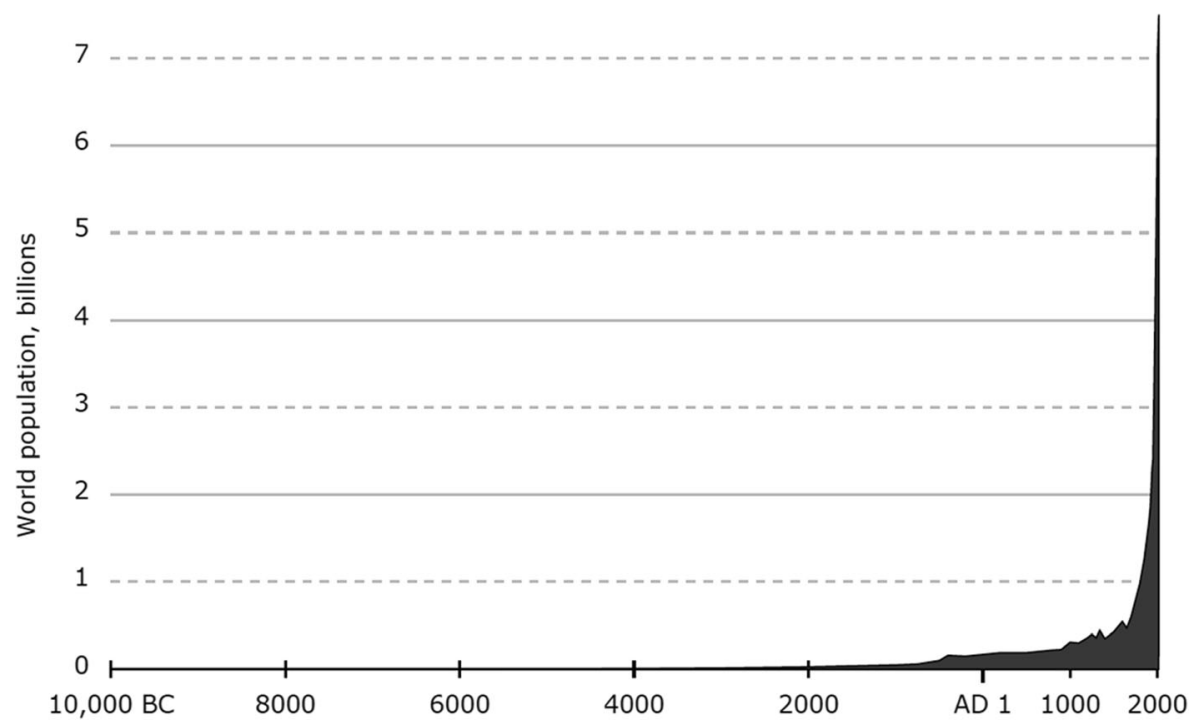

Fig. 1 The Demographic Transition (Livne, 2019) 
and the human population's geometrical growth (Malthus, 1985), and Marx considered overproduction and consequent stagnations as tendencies inherent to capitalism (Marx, 1976). Yet these theories still conceived of human history as progressive-human growth and historical advent were bound to continue following periodic cyclical crises that slowed them down.

In more recent discussions, however, references to progress's ultimate and categorical end are ever present. Economists are suggesting that "the rapid progress made over the past 250 years could well turn out to be a unique episode in human history" (Gordon, 2016) and that "the 21 st century may see a return to a low growth regime" (Piketty, 2014, p. 72). This flattening of economic growth curves would not be due to a temporary recession, but to long-term tendencies: the exhaustion of past revolutionary innovations, these innovations' historical singularity, and the unlikelihood that similar breakthroughs will ever occur again. ${ }^{1}$ Similarly, consider the basic assertion of environmentalists that any growth occurs within the limits of Earth's categorical physical limits and will have to adjust to these limits (Meadows et al., 1971). Here and elsewhere, progress is regarded as achievable, but only at a price that is too high and bound to ultimately spark a cataclysmic and regressive collapse (D'Alisa et al., 2015). If the modern condition was a state of constant expansion, a pivotal challenge in our time is how to moderate and control this expansion, handle excess, and bend the curves that Figs. 1 and 2 present (cf. Abbott, 2014).

This article analyzes such efforts to delineate, negotiate, and govern the limits of the modern project as sociological endeavors. The stakes of these endeavors are extremely high. For one thing, they mark out modernity's farthermost reaches - the points beyond which meaningful progress is unachievable, meaningless, or self-destructive. They therefore delimit (read: define) human agency. By representing a certain state of affairs as modernity's farthermost possible frontier, the people carrying out projects of placing limits on progress make claims on the boundaries of possible human achievements and the limits by which societies should live.

The case study I use to illustrate this point is the attempt to contain medicine's effort to prolong human life. Prolonging life and postponing death is perhaps the modern medical sciences' most emblematic goal. Medicine's capacity to cure disease, reduce mortality, and prolong existence is a most palpable testimony to human beings' success in controlling nature and transcending the limits of their own biology. In the past few decades, however, medical advent has attracted much doubt. Many argue that medicine often prolongs lives of compromised quality and that scientific triumphs over disease result in agonized states of existence, which few find meaningful. Since the cost of lifeprolonging treatments outpaces economic growth, the prolongation of these unwanted lives also puts a financial burden on developed countries' economies. The question of limits therefore manifests as a multifaceted challenge, in part financial, in part medical, in part existential: when should we admit the limits of our capacity to control nature, stop prolonging life, and allow death to occur?

I analyze how this question is addressed in the US, asking how social institutions in the country enact limits on medicine and life prolongation. The focus on the US allows

\footnotetext{
${ }^{1}$ Compare this to the opposite tone of Galbraith's arguments (1958). "The Affluent Society" pointed at the new policy opportunities that growth has created, not the adjustments needed once society exhausted its growth potential.
} 


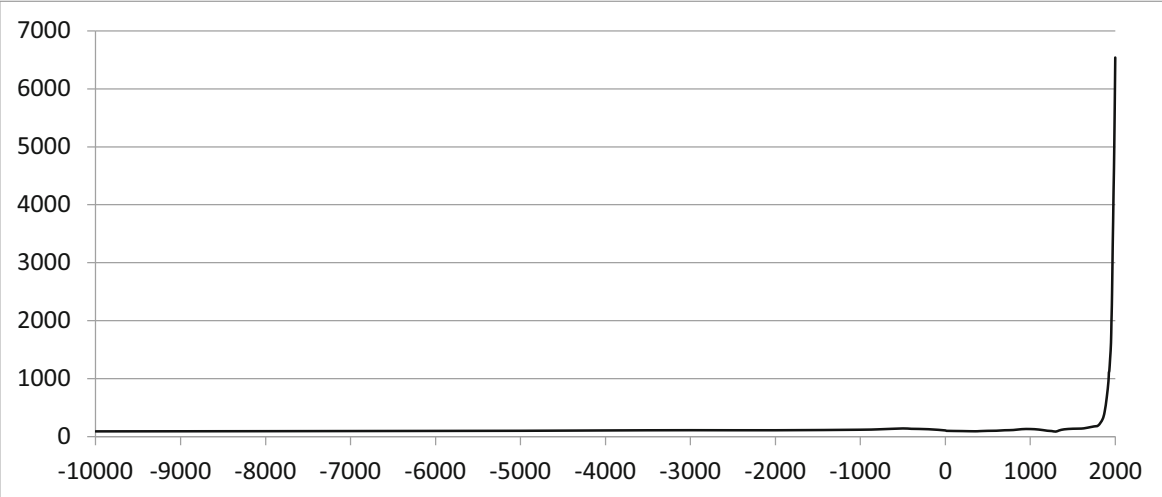

Fig. 2 World GDP per capita (adapted from De Long, 1998)

me to examine the enactment of limits as it plays out in a relatively individualized and decentralized market system. Countries with centralized healthcare systems have been able to exercise direct controls on medical utilization and spending. A quintessential and often-cited example is the United Kingdom's National Institute for Health and Care Excellence (NICE), which stipulates a ceiling price of $£ 30,000$ for treatments that prolong life by an average of one year, adjusted for quality (Ashmore et al., 1989). Treatments whose cost effectiveness does not meet this threshold may be covered only after additional review. By contrast, US healthcare's decentralized market structure means that such direct policy controls are unlikely to emerge and be effective (cf. Hacker, 2002). The US places much emphasis on individual patients' right to participate in decisions on their care and provide their "informed consent" to treatments they wish to receive or forgo, which makes such decisions relatively contingent and idiosyncratic. Furthermore, medical decision-making in the US is distributed across numerous professional and organizational actors: patients hold different insurance policies, receive care in different hospitals and from different physicians-with each having different policies and standards for how and how far to go in treating severe illness.

In this context, I argue that limits on life-prolongation in the US have been enacted not through central standards and regulations, which states apply high-handedly on organizations, professionals, and patients, but through a pervasive moral, professional, and economic power - a regime of valuation that informs the judgment of individual patients, clinicians, and organizations and impacts how they think and reflect about themselves, their interests, and their goals (see Lukes, 2005). My focus is on groups of patients and clinicians who, beginning the 1960s, mobilized to challenge modern medicine's categorical emphasis on prolonging life and postponing death. Their mobilization institutionalized into an influential movement, hospice and palliative care, which launched extensive public and expert discussions on the worth of life in severe illness. These discussions mobilized millions of people to reflect and make statements on the value they found in a life with various medical conditions, which effectively marked the limit beyond which life would no longer be meaningful to them.

The argument progresses as follows: First, I conceptualize the sociological project of enacting limits theoretically by developing the term economization. Second, I draw on 
a combination of historical, interview, and ethnographic data to explain how the intuition that less care is oftentimes better has anchored itself in professional, popular, and economic discourses in the US and how the process of limiting care at the end of life unfolds in practice. The article's conclusion invokes several other examples for how the question of finitude and the challenge of economizing play out in contemporary societies.

\section{Economization and limits}

I propose the term economization - and its conjugations as a verb, adjective, and verbal adjective: to economize, economized, and economizing - as instructive in analyzing social dynamics around limits and finitude. In current economic sociology discourse, the term and its multiple conjugations are vague. They carry numerous and often inconsistent meanings, in part because their related noun (economy) has acquired different connotations over the past century (see Mitchell, 2002; Polanyi, 1992). To add to the conceptual vagueness, economic sociology has not developed its own theoretical notion of "economy" (Granovetter, 1990; Granovetter \& Swedberg, 2011; Krippner \& Alvarez, 2007). The field's dominant paradigm centered on Mark Granovetter's idea of embeddedness and took the market, not the economy, as its main object of interest. When the term appeared in his writing, Granovetter referred to the economy as a realm that may be embedded in society to different degrees (Granovetter, 1985). This concept of embeddedness enveloped "the asocial market construct in social relations, all the while preserving intact the notion that somewhere there was a hard core of market behavior existing outside of social life" (Krippner, 2001, pp. 777-778). To this day, Granovetter uses the term economy in a colloquial and untheorized fashion, as something "having to do with the production, distribution, and consumption of goods and services - what we might call the 'hard core' of economic activity" (Granovetter, 2017, p. 2). Granovetter and his followers have effectively adopted economists' definition of the economy (Krippner, 2001).

Other and more culturally inclined branches of economic sociology avoided defining "economy" (and hence economization) for the opposite reason: they sought to transcend all distinctions between economy and non-economy, treating economic institutions as quintessentially social (e.g. Almeling, 2007, 2011; Anteby, 2010; Chan, 2009, 2012; Kameo, 2015; Lainer-Vos, 2012; Quinn, 2008; Wherry, 2011). Commonly known as "morals and markets" scholarship, this approach took on studying economies as societies - places where collective conscience, identities, and moral categories are formed (Fourcade \& Healy, 2013, 2016). Viviana Zelizer, who laid out the field's most elaborate analytical framework, defined her approach as relational sociology: studying how people create and negotiate distinctions between different social relations, economic or non-economic (Bandelj, 2020; Zelizer, 2004a, 2004b, 2011, 2012). The same applied to scholars in the emergent field of valuation studies, who used the terms "values" and "valuation" in analyzing all human activities, whether or not they are traditionally regarded as "economic" (Beckert \& Aspers, 2011; Boltanski \& Thévenot, 1999; Christin, 2018; Espeland \& Sauder, 2007; Kiviat, 2019; Stark, 2000). This 
rendered attempts to define economy and economization processes self-defeating and counterproductive (Çalişkan \& Callon, 2009). ${ }^{2}$

My own theorization of the term "economy" embraces the strong view that no apriori distinctions should be drawn between "economic" or "social" domains. Yet with that in mind, I maintain that a redefinition of the term "economy" as an important object of analysis in economic sociology is due. Following Çalișkan and Callon, I treat "economy" as a processual outcome and shift the discussion from defining what economy means to analyzing economization processes (Çalişkan \& Callon, 2009, 2010). My approach, however, goes beyond Çalișkan and Callon's argument, which defined economization as the qualification of certain things and behaviors as "economic" using an economic theory. I view economization as a process that can develop independently of any theory. Following economic anthropologists and valuation scholars, I define economies in general and market economies in particular as "regimes of valuation"-relatively organized and enduring patterns of ascribing cultural, moral, and financial worth to people, behaviors, qualities, and objects (Abend, 2014; Appadurai, 1986; Beckert \& Aspers, 2011; Boltanski \& Thévenot, 1999). Economization means a purposeful establishment, or unplanned emergence, of such a regime of valuation - an overdetermined process that may have multiple sources. Economization and economies are not necessarily market-based, nor do they have to be monetary (E. P. Berman, 2014). One can think, for example, of socialist and communist economies; "moral economies" (Abend, 2014; Fontaine, 2014; Scott, 1976; Thompson, 1971); domestic, informal, and gendered economies (Folbre, 1991, 2001; Portes, 1994; Zelizer, 1994); and non-market economies, which draw on reciprocity and redistribution (Polanyi, 2001). Polanyi aptly observed that, "The anthropologist, the sociologist or the historian [face] [...] a great variety of institutions other than markets, in which man's livelihood [is] embedded" (Polanyi, 1992, p. 30). Defining economies as regimes of valuation, however, means an even more inclusive definition of economy, since there are many regimes of valuation that do not directly pertain to human livelihood and material welfare (Lamont, 2012). These would be, for example, economies that emerge around civic regimes of valuation that ascribe value based on contribution to collective virtues, or economies of aesthetic value that valorize inspiration, passion, and any break with the quotidian, usual, and mundane (Abend, 2014; Boltanski \& Thévenot, 1999; Polanyi, 1977).

Having defined economization, let me emphasize three important characteristics of economization processes as I see them. First, economization involves stipulating, and hence somewhat binding, the ascribed value of the things included in the economy in question. When determining value, one necessarily delimits it (Graeber, 2002). For example, assigning monetary value - a price - to a certain object is an assertion that this object's monetary value does not rise above or fall below this price. By contrast, characterizing something as "priceless"-i.e. labeling it as having infinite, indefinable monetary worth - is equal to stating that it does not belong in a monetary economy. This was, for example, the case with children, who in the early twentieth century gained sentimental value and lost financial value. Children became priceless, meaning that

\footnotetext{
${ }^{2}$ I respectfully disagree with Çaliskan and Callon's (Çalișkan \& Callon, 2009) claim that Granovetter avoided writing about economization for this reason. This claim applies far better to scholarship on morality and valuation than to the "embeddedness" paradigm.
} 
they were excluded from the monetary economy (Zelizer, 1985). ${ }^{3}$ In the case of end-oflife care, I will show that specifying the value that one ascribes to life involves marking the limits beyond which life would be meaningless, hence delimiting and binding life's value.

Second, as regimes of valuation, economies enact social hierarchies and boundaries. Capitalist market economies, for example, hierarchize people and organizations using credit scores, bond ratings, and loyalty programs that differentiate between "silver," "gold," and "platinum" members (Fourcade \& Healy, 2016). Economization involves deploying such classifications, scales, and status markers, which grant differential access to resources and benefits. Beyond establishing hierarchies, economization processes also enact boundaries that determine inclusions and exclusions from a certain economy. The meaning of exclusion is evident to anyone living without a credit-score or a social security number. It is not about being undervalued but about not being valuated at all, which means non-existence in a certain economy. Consider, for example, the case of women who were assigned their husbands' credit scores and lost all credit history upon divorcing them, or residents of redlined, majority-black neighborhoods who were virtually excluded from credit markets. Struggles for inclusion in such cases were fights for economic citizenship and had quintessential civic characteristics (Krippner, 2017; Robinson, 2020; Taylor, 2019). Success in these struggles, however, meant inclusion in the credit economy and subjection to its hierarchical order at the same time (Taylor, 2019). Economization, therefore, involves drawing social boundaries and establishing criteria for belonging, which hierarchize and differentiate among those included.

Lastly, regimes of valuation influence behavior. Knowing that credit ranking agencies monitor and valuate financial behaviors makes people reflect upon and adjust their conduct (Fourcade \& Healy, 2016); knowing that the US News and World Report valuates academic departments by certain criteria leads those departments to change their policies and adopt strategies that advance them in the ranking (Espeland \& Sauder, 2007, 2016); and knowing that online magazines valuate articles by the number of readers they attract and the amount of time these readers spend reading them may impact both writing and editorial decisions (Christin, 2018). This is "reactivity," in Espeland and Sauder's terms (2007), an impact attained not by forcing certain patterns of behavior, but through valuations that make people (or organizations) self-manage in order to advance in a certain economy. Economization, therefore, is not only a process by which an economy emerges, but also by which this economy structures the behaviors of those subjected to it.

In what follows, I draw on the case study of US end-of-life care to illustrate an economization process in which a hierarchical regime of valuation consolidated, applied itself to some, excluded others, and differentiated among those included. This case shows that economization does not need to start from economists, economic theory, or economic concepts (Çalişkan \& Callon, 2009, 2010). An economization process can originate from completely anti-economistic thinking - as in cases where

\footnotetext{
3 The idea stands even if we consider singularities, i.e. unique goods that are incommensurable with others. Such goods may still be economized. As Lucien Karpik argues, one can agree that Rembrandt and Mondrian are both of singular quality and that no hierarchy between them can be legitimately established, yet at the same time reason why they find value in one and not the other (Karpik, 2010, pp. 12-13). Doing so means marking out the limits of, say, Rembrandt's aesthetic value by comparing it to Mondrian's.
} 
socially patterned regimes of valuation originated from religious (Abend, 2014; Weber, 2011), aesthetic (Karpik, 2010), or civic discourses (Boltanski \& Thévenot, 1999). In the case of end-of-life care, I show that much of the economization process is attributable to a humanistic moral thinking. Once established, this economy assumes the form of a life domain whose particular patterns of valuation make it relatively differentiated from others. This regime establishes value and, by that, governs and limits the people and objects it includes.

\section{Methods}

My empirical analysis draws on a combination of historical, interview, and ethnographic data whose collection process I described in more detail elsewhere (Livne, 2019, pp. 264-272). I conducted the ethnography and interviews in a large metropolitan area in California, where the hospice and palliative care expertise is relatively developed and seen as a model for how end-of-life care should be practiced. Within this area, I chose three hospitals that served different demographics - a public safety-net hospital, a private hospital, and an academic medical center. Each of these hospitals had a palliative care team, ${ }^{4}$ which I joined for a total of 80 days over the course of 13 months during 2011-2012. I shadowed clinicians in their day-to-day work and participated in their staff meetings. I sat in on family conferences, observing clinicians talk to patients and their families about terminal diagnoses and grim prognoses, the goals of their medical care, and whether or not to withhold or withdraw life-sustaining interventions. I watched clinicians as they read patients' charts and formulated opinions regarding their conditions and chances of survival. I observed clinicians talking among themselves about whether to continue prolonging patients' lives, given their medical conditions and their stated or unstated wishes. During the same period, I conducted 80 in-depth interviews with clinicians and administrators from these three hospitals, as well as three additional hospitals. Interviewees included nurses, social workers, case managers, administrators, and physicians of different specialties. I employed a targeted snowball sampling strategy, relying on interviewees referring me to other interviewees, while purposefully aiming to include people of various professional backgrounds, clinical stances, and demographic groups.

These data allowed me to examine the valuation of life and its prolongation in contemporary hospitals. In order to add a historical dimension to the analysis, I reviewed all congressional hearings on the topic (see Appendix), all of the articles that were published in the two leading US Medical Journals (New England Journal of Medicine and Journal of the American Medical Association), all of the articles published on the topic in The New York Times, and a selection of noteworthy publications in other newspapers. Drawing on bibliographic lists, I compiled an exhaustive list of books that were published on the topic beginning in the 1950s, as well as publications of the main advocacy organizations for hospice and palliative care.

\footnotetext{
$\overline{4}$ The empirical sections lay out the definition of palliative care and its historical development.
} 


\section{An uneconomized approach}

Consider an uneconomized approach to health, medicine, and life-prolongation. In August 1972, the US Senate's special committee on age and aging held its first hearing on the topic of care for the dying. One speaker, Maryland physician Laurence Foye, voiced an unyielding position:

Every physician can [...] describe a number of patients for whom he predicted a rapidly fatal outcome - saying, 'I knew they were going to die' - and was wrong. [...] If a physician witholds maximum effort from patients he considers hopelessly ill, he will unavoidably withhold maximum effort from an occasional patient who could have been saved. Patients will die because of the physician's decision not to treat actively. This approach and concern cannot be fostered or condoned $[\ldots]^{5}$

Foye argued that no life-prolonging care, and consequently no spending on this care, should ever be spared. Life was priceless, its value unbound, and no economization of the care necessary to prolong it was possible. Categorical as it was, this position was unexceptional and echoed a strong modernist narrative that was dominant during the period. In the US in particular, the post-World War II decades provided fertile grounds for such sentiments: scientific triumphs ranged from increased control over infectious diseases, to military victories over the Axis Powers, to successes in the race to space. Public imagination was full of futuristic visions of additional victories. "Science," the title of a 1945 report to the President declared, was "an endless frontier" (Bush, 1945) - an explicit reference to the United States' history as a frontier society (Turner, 2008):

It has been basic United States policy that Government should foster the opening of new frontiers. It opened the seas to clipper ships and furnished land for pioneers. Although these frontiers have more or less disappeared, the frontier of science remains. It is in keeping with the American tradition-one which has made the United States great - that new frontiers shall be made accessible for development by all American citizens (Bush, 1945).

Disease was an especially promising frontier to conquer, and mid-twentieth century scholars took great pleasure in rooting their sentiments in both local traditions and universal principles. In a widely read book, René Dubos dated medicine's boundless ambition to the Enlightenment, when the cultural premises underlying modern science emerged. "Condorcet," he wrote, "envisaged an era in which man would be free from disease and old age and death would be indefinitely postponed." Then he invoked the founding fathers: "Benjamin Franklin made similar predictions. To achieve old age had a universal fascination" (Dubos, 1959, p. 18). With proper investment and human effort, it seemed like there were no limits to what human reason could achieve through medicine.

\footnotetext{
5 "Death with Dignity: An Inquiry into Related Public Issues," Hearing before the Special Committee on Aging, United States Senate, 92nd Congress, 2nd session, August 7, 1972, Part I, p. 23.
} 
This vision of scientific growth paralleled growth in financial investment. The postWWII decades were a period of great economic prosperity, in which the US embraced an expansionary healthcare policy. The Hill-Burton Act, and later on the passing of Medicare and Medicaid, increased the number of medical schools, medical professionals, hospitals, research centers, and insured patients who could access health services. Increased federal funding gave rise to big medicine and instigated the corporatization of US healthcare (Starr, 1982). Pharmaceutical companies, medical device producers, private insurers, and hospital networks grew into an enormous corporate sector, making the ethos of medical progress materialize in a combination of endless professional ambition and overwhelming financial capacity. There was a thriving medical-industrial complex, which aspired to counter all illnesses, almost regardless of severity (Kaufman, 2015; Relmand, 1980).

Many physicians embraced the ethical stance that, because medicine was progressing and many studies and clinical trials were underway, doctors were obliged to use everything they had in their professional toolkit to save lives, or at least to prolong life until a cure became available. In the Journal of Clinical Oncology, eminent oncologist James Holland proposed using a new taxonomy for malignant tumors: curable, sub-curable, and procurable:

The procurable cancers - I do not believe the temporary embarrassment of our ignorance warrants perpetuation of the term incurable - do not exclude anecdotal case reports of chemotherapeutic eradication, although a systematic study according to the rules has not been accomplished. (quoted in Baszanger, 2012)

Cure for cancer - and, in principle, for any disease - seemed to be around the corner. Of course, medicine could not do everything: it confronted a scientific frontier - areas that science had not yet studied and conquered. But within medicine's temporary and always expanding boundaries, doctors could - and were indeed obliged - to embrace maximalism: there was no restraint on their practice, no regime that bound its value, and hence no economy of life-prolonging interventions.

Consider this maximalist ethic as analogous to the organization of pre-modern political power, as Michel Foucault described it. The political power of PostWestpalian monarchs was limited only by the external borders of their kingdoms. Within these borders there was effectively no limit on the violence they could legitimately exercise - the sovereign had the absolute right to torture, kill, and forgive. This, however, changed in the eighteenth century when "the principle of mildness of punishment" appeared, and with it the necessity to provide utilitarian justifications for the use of power, violence, and punishment. This economy of violence meant that political power was legitimate only so far as it obeyed utilitarian reason-for example, served the purpose of effectivly managing crime (Foucault, 2008, pp. 10-11, 45-46).

In a similar way, the maximalist ethic saw medicine as restrained only by an extrinsic boundary - the outermost frontier of scientific capacity. Yet in the US, starting in the 1960s-1970s, parallel to the sharp rise in healthcare utilization, several rationales of economization arose with regard to medicine's limits at the end of life. Like political reason in the eighteenth century, they introduced intrinsic boundaries, which economized the imperative to prolong life and counter disease indefinitely. Economization meant a shift from medical maximalism to a more measured and restrained orientation, 
which hinged on determining, and hence binding, the value of medical treatments and the worth of the lives they sustained. In this particular case, economization drew on a tripartite regime of valuation: medical valuation, monetary valuation, and patientfocused valuation.

The medical regime of valuation was based on a clinical outlook, which evaluated the benefit of life-prolonging and life-sustaining interventions in severely ill patients and oftentimes criticized physicians and the treatment they provided as "aggressive," "futile," and "overly ambitious." The monetary regime of valuation hinged on estimations of the cost of care at the end of life and informed corollary judgments on "overspending" and "wasteful" financial conduct in the area. The patient-focused regime of valuation defined patients as the main actors who should determine the value of life, and consequently, what counts as a life not worth living.

Each of the next three sections is dedicated to one of these three regimes.

\section{Medical valuation}

Within the medical profession, the maximalist frontier orientation reflected in Foye's and Holland's statements did not go unchallenged. Much of the ambivalence toward science and technology, which characterized the post-WWII decades, was directed at medicine. "Science has brought evil as well as good," declared the second Humanist Manifesto in 1973:

Using technology wisely, we can control our environment, conquer poverty, markedly reduce disease, extend our life-span, significantly modify our behavior, alter the course of human evolution and cultural development, unlock vast new powers, and provide humankind with unparalleled opportunity for achieving an abundant and meaningful life. The future is, however, filled with dangers. In learning to apply the scientific method to nature and human life, we have opened the door to ecological damage, over-population, dehumanizing institutions, totalitarian repression, and nuclear and bio-chemical disaster (AHA [American Humanist Association], 1973).

Throughout the 1960s and 1970s, US medicine drew criticism for its "interventionist bent" (IoM, 1997, p. 47). Journalist Lynn Payer described US medicine as "aggressive," writing that "American doctors want to do something, preferably as much as possible. [...] They often eschew drug treatment in favor of more aggressive surgery, but if they do use drugs they are likely to use higher doses and more aggressive drugs" (Payer, 1988, pp. 124-125). Similar observations echoed in much of the period's critical writing on medicine (Bunker, 1970; Notzon et al., 1987; Sontag, 1978) and in classical medical sociology works (Freidson, 1970, p. 258; Parsons, 1951, pp. 466-467). The modern hospital, which became a most central medical institution by the 1920 s, was an emblem of dehumanizing and technical medical professionalism that treated patients as objects and not as people (Chambliss, 1996; Rosenberg, 1987; Stevens, 1989).

Many medical practitioners were concerned about these developments. Prominent Harvard physician Alfred Worcester dedicated an entire book to arguing against aggressive life-prolonging treatments in elderly patients, writing that physical decline 
was "inevitable" and "not pathological," and should therefore be treated as "a perfectly natural process." He recommended that physicians who treat the elderly adopt a "regressive régime"-namely, phase out medical interventions and allow physical degeneration to take its natural course. Oncologists, Worcester contended, should not treat cancers in elderly patients, and dentists should stop offering them dental prostheses, since teeth loss may be "the natural safeguard for the aged against overeating." "Artificial teeth and culinary triumphs," he concluded, "are the disguised enemies of a healthy old age" (Worcester, 1961). While physicians in later decades did not go as far as rebuking mushed food and protein shakes, many of them questioned the limits of what medicine could achieve and the consequences of pursuing unrestrained lifeprolongation. Oncologists during the 1950 s were explicit in stating that their capacity to prolong life was very limited; oncology journals often referred to chemotherapy as "palliative care"- treatment that could control symptoms and reduce pain and, at the same time, prolong life (Baszanger, 2012). Outside of oncology and mainstream medicine, groups of physicians and non-physicians organized numerous conferences that laid the foundations of the field of bioethics. End-of-life care and the limits of modern medicine were and continue to be among their main topics of concern (R. C. Fox \& Swazey, 2008; Jonsen, 1998).

The most consolidated and influential body of clinical practice and knowledge that took on addressing the question of medicine's limits was Hospice and later on Palliative Care. Hospice began as a morally motivated call from clinicians to acknowledge the limits of medicine, human agency, and scientific progress - a search for a medical diminuendo that would replace an otherwise unmitigated crescendo. Hospice advocates formulated and applied a new regime of medical valuation, which assessed the worth and quality of various lives and, consequently, the morality and professional appropriateness of the medical interventions that sustained these lives. Echoing ideas such as Worcester's, hospice advocates criticized medicine for treating death as an abnormality - a negative and traumatic event that should always be battled and postponed. Modern medicine, they argued, denied the finitude of human existence and treated disease as if life could be prolonged indefinitely. Modern hospices, by contrast, embraced death as integral to life: they replaced medical maximalism-the unquestionable and categorical emphasis on prolonging life and postponing death in all circumstances - with a focus on facilitating comfortable and dignified deaths. "To go on pressing for acute, active treatment at a stage when a patient has gone too far and should not be made to return is not good medicine," wrote London clinician Cicely Saunders, the hospice movement's most eminent pioneer (Saunders, 1969, pp. 57-58). She and her disciples found the value of care not in medical interventions that transcended nature, but in their suspension and replacement with an acceptance of the limits of human life and medical capacity.

Hospices took hold in US healthcare remarkably fast. In the mid-1960s, a group of clinicians from the Yale Medical Center launched the first hospice pilot program in the country. Several years later, they parted with the medical center and instituted an independent organization, Hospice, Inc. of New Haven, which admitted its first patient in 1974 (Buck, 2005). By the 2010s, American hospices served an estimated 1.65 million people, and $44.6 \%$ of all deaths in the country occurred in a hospice program (NHPCO, 2012) (see Fig. 3). US hospices transformed from a radical and somewhat marginal alternative to mainstream medicine into a noteworthy part of the medical 


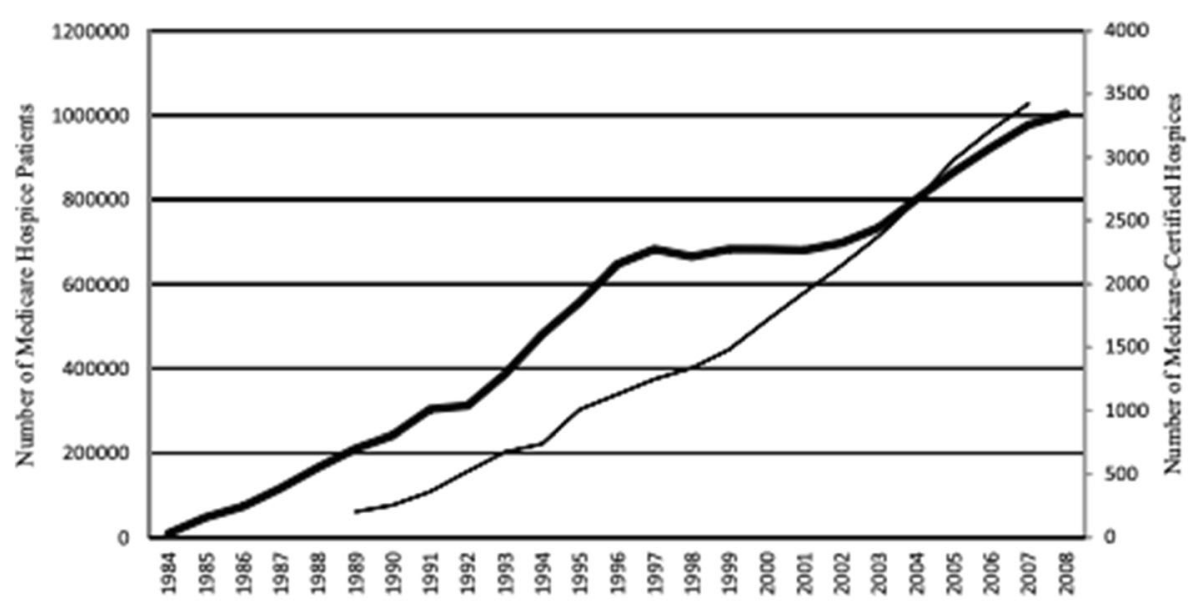

- Medicare Hospice Patients

Medicare-Certified Hospices

Fig. 3 Number of Medicare Certified Hospices and Medicare Patients Dying in Hospice (Livne, 2014)

profession. They institutionalized in both senses of the term: hospice was delivered by a record number of hospice institutions and its principles became more stable and habituated.

Part of this institutionalization was formal: professional organizations and regulators set standards for hospice care, trained and tested clinicians, and evaluated the quality of end-of-life care in different states (Livne, 2019; Siebold, 1992). Another part was informal: popular perceptions of a "good death" revolved around how hospice pioneers defined it - a painless, "peaceful," and "natural" death, with minimal medical interventions, which occurs at home while surrounded by "loved ones" and after reaching psychological, spiritual, and emotional "closure" (Timmermans, 2005). Ideas that were initially anti-medical, anti-professional, and anti-institutional-e.g. Kubler-Ross's (1969) call to de-medicalize death, allow people to die at home, and provide care that draws on personal relations rather than medical guidelines - became the new rule book of hospice practitioners, who now pursued the "acceptance" of death as a key goal of care (Broom, 2015).

The field of palliative care developed in the 1990s as an extension of hospice. If hospice treated unquestionably dying patients, palliative care targeted patients who were still in the hospital and were likely to die in the non-immediate future. Medicare regulations determined that hospice would apply to patients whose life expectancy was six months or less if their disease developed on its predicted course (Werth \& Blevins, 2002); palliative care, on the other hand, moved conversations on end-of-life care to an earlier stage, in which clinicians, patients, and relatives would negotiate the gray areas of terminal diagnosis.

As a field of medical practice, palliative care developed as an "elitist" endeavor, which several major philanthropic organizations (notably, the Open Society Institute and the Robert Wood Johnson Foundation) funded with over a quarter billion dollars (Patrizi et al., 2011, p. 18). In 1994, George Soros's Open Society Institute (OSI) launched Project On Death in America (PDIA). Over ten years of existence, the project sought to simultaneously build a "professional field" for end-of-life care and "change 
the culture of dying" in the US. PDIA paid the salaries of 87 fellows (mostly physicians), whom it ordained as the field's "leaders." By 2003, this group authored over 2000 articles in the area and raised over $\$ 113$ million for research (Clark, 2013). It topicalized the end of life (Broom, 2015) - i.e. made "the end of life" a visible, recognizable topic in medical journals and in the popular media (Figs. 4 and 5). PDIA aimed to send these fellows-turned-leaders back to their hospitals and medical schools to train the next generation of clinicians, setting the target of placing at least three faculty members who promote end-of-life care in all U.S medical schools (OSI, 2004:55). The program also supported writing curricula and textbooks on the topic for physicians, nurses, and social workers (Clark, 2013).

Hospice and palliative care's agenda was both moral and professional. The moral concern over modern medicine's over-ambition, let alone its dehumanizing qualities, transformed into a set of medical standards that clinicians learned, taught, published, and applied at the bedside. This professional stance was key to the economization of dying. It offered an alternative to the modernist frontier mentality with a critical scrutiny of the value of medical interventions, labelling many procedures as futile, immoral, and medically misinformed. The limits hospice and palliative care set on medical treatment were intrinsic rather than extrinsic: clinicians were no longer constrained just by the areas science has not yet reached and conquered. Economization, rather, pervaded their professional judgment: part of practicing good and responsible medicine was reflecting, moderating, and restraining the intensity of the care that they provided.

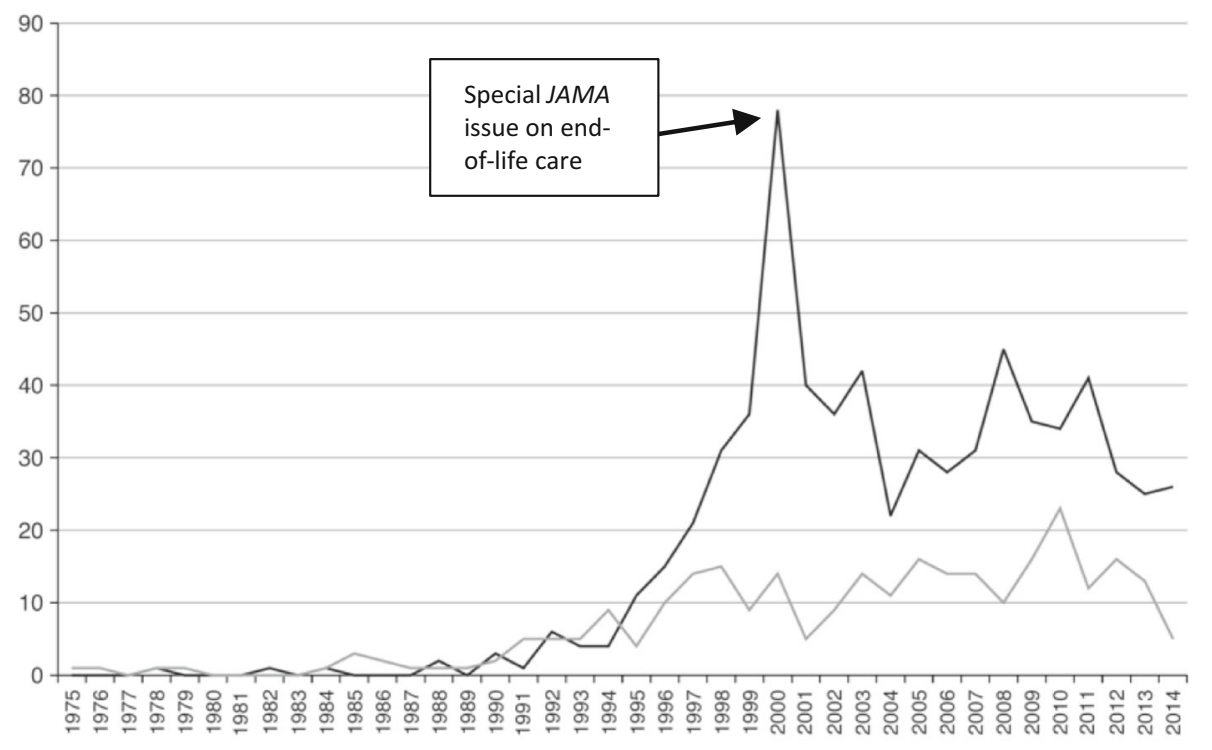

- Journal of the American Medical Association

- The New England Journal of Medicine

Fig. 4 Number of articles mentioning "end of life" in top U.S. medical journals. The number of total citable items (both articles and reviews) in the New England Journal of Medicine remained fairly stable in 1997-2014 (an average of 354 items a year) and declined in the Journal of the American Medical Association by $40 \%$ (comparing the averages of 1997-2004 and 2005-2014). This makes the relatively stable number of articles that mention end-of-life care even more indicative of the field's prominence (data are from Journal Citation Reports) 


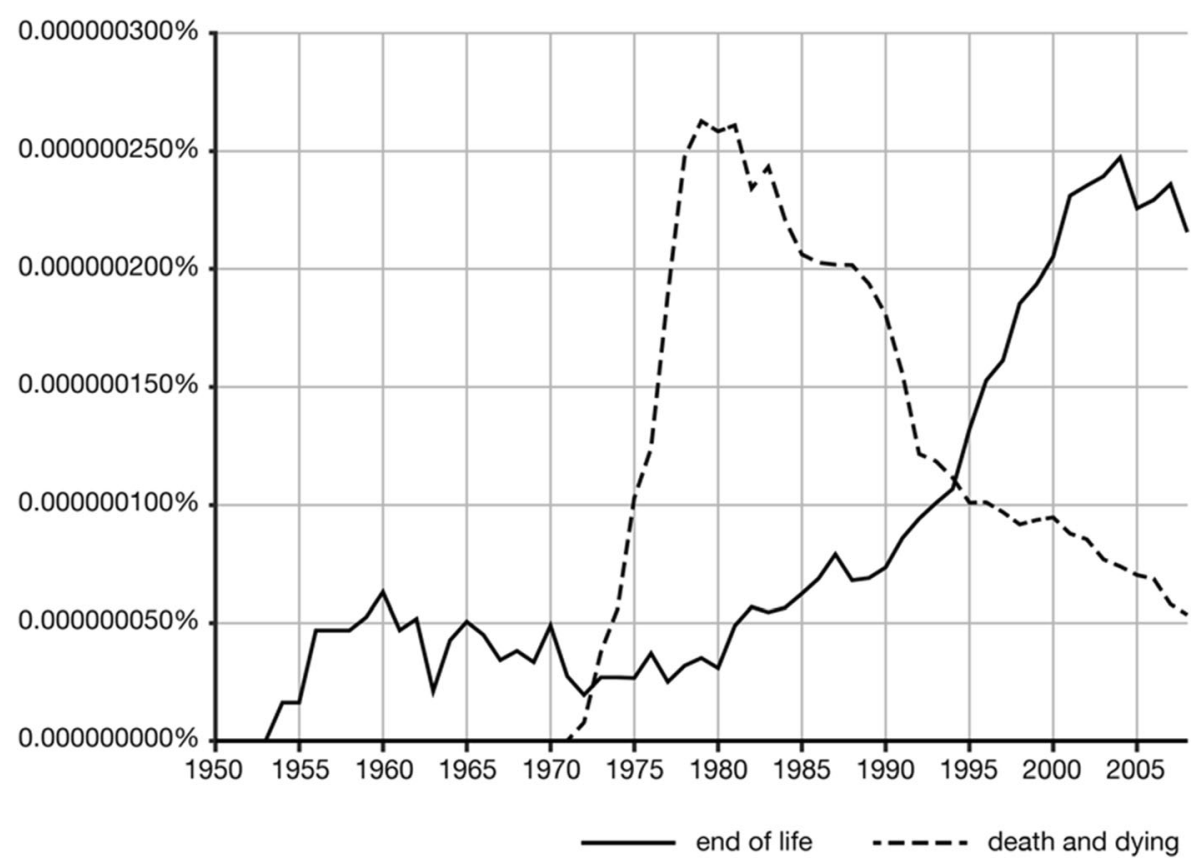

Fig. 5 Growth in the proportion of books on death and dying (Livne, 2019)

\section{Monetary valuation}

A parallel, related, and crucial component of the economization of end-of-life care was monetary valuation: judgements on the appropriate limits for monetary spending on life prolongation. Literature on morality in markets has analyzed cases of institutions that monetize the value of lost lives - most notably, life-insurance companies and courts adjudicating civil lawsuits on wrongful deaths (e.g. Chan, 2009; Zelizer, 1979, 1985, 2004a). Making a determination that a patient is too expensive to treat, however, is an even more contested case, since monetization here takes place ex ante and effectively circumscribes death (cf. Quinn, 2008, pp. 738-740).

Rising healthcare spending in developed countries has inspired lively ethical discussions on how to valuate medical care and the lives that it prolongs monetarily, enact spending caps, and institute rational mechanisms for care rationing (Callahan, 1987, 2009; Singer, 2009; Ubel, 2000). In the US, however, most of these visions and proposed policies are theoretical, and the reality on the ground is remotely different from them. The Medicare statute - the closest the country has ever come to a centralized and standard-setting healthcare system - determines that Medicare should provide coverage for all "reasonable and necessary" treatments, without defining what qualifies as "reasonable" or "necessary," let alone specifying how costs should play into consideration. Apart from choosing the least costly alternative among equivalent treatments (itself a difficult judgment to make), the Centers for Medicare and Medicaid Services have not taken costs into account explicitly when making determinations on coverage (J. Fox, 2010; Neumann \& Chambers, 2012). The case is similar with concrete medical decisions at the bedside: clinicians can stop treatment because they 
consider it "futile," yet there are no bureaucratically imposed rules requiring them to withdraw or withhold care from patients just because their treatment is too expensive.

In practice, the monetary valuation of end-of-life care in the US operates as a Baxterian "lightweight coat that one can throw off at any time" (Weber, 2011, p. 177) - a general and non-binding intuition that too much is being spent on dying patients and therefore less should be spent on them. This intuition has permeated the considerations of policymakers, hospital administrators, and at times clinicians, informing how they conduct themselves when life-and-death decisions are at stake. I will highlight the impact that three groups of actors have had in fostering this intuition: hospice advocates, health economists, and palliative care advocacy organizations.

Hospices largely overlooked financial questions in their first decades of existence. Hospice advocates and practitioners produced hundreds of publications during the 1960s and 1970s, but they hardly ever included explicit discussions of money, budgets, and finance. Bibliographical lists of hospice literature in the 1970s had no "economics" or "costs" section, and did not list any book that focused on the topic (Fulton, 1977, 1981; A. H. Kutscher, 1969, 1974; M. Kutscher, 1975; Miller \& Acri, 1977; Poteet, 1976; Sell, 1977; Simpson, 1979, 1987). ${ }^{6}$ This lacuna partly stemmed from the fact that these authors were idealist clinicians, not economists, and therefore did not consider themselves qualified to opine on finances. Many of those who did opine did so antagonistically and advocated for relinquishing monetary payments of any type, basing the hospice economy on donations, and relying on volunteer work (Livne, 2014). In their eyes, the value of life and end-of-life care was moral and spiritual, not monetary, hence no monetary economization was legitimate.

During the same years, however, a central and powerful faction within the hospice movement pushed to expand and attract more funding for hospice care. In the late 1970s, a group of entrepreneurial advocates established the National Hospital Organization (NHO) and took on lobbying Congress to have Medicare pay for hospice. The group's first attempt to introduce a bill failed in 1980, but its members redrafted new proposals and met with lawmakers in Washington regularly (Beresford, 2007). Their most successful argument throughout the period was that hospice was cheaper than hospitals. As many of them noticed, "the success of hospice proponents in negotiating funding for $[. .$.$] reimbursement is affected by their ability to demonstrate hospice care$ systems' cost-saving potential"' (Osterweis \& Szmuszkoviz Champagne, 1978).

The argument that hospice costs less than conventional medicine made intuitive sense. Hospice focuses on treating pain and symptoms and typically takes place at home, which should be cheaper than intensive life-sustaining care in hospital. Yet demonstrating this intuition empirically proved difficult. Several studies in the late 1970s that evaluated the relative cost of hospice were equivocal (e.g. Comptroller General, 1979; Hospice Project Task Force, 1980). The Health Care Financing Administration (HCFA) was doubtful and recommended that Congress wait for conclusive results from a more rigorous and federally funded study that was launched during the period. NHO advocates, however, continued pressure on Congress, claiming that data analysis in this study was slow. They insisted

\footnotetext{
${ }^{6}$ These lists included 24,421 titles in total (some appeared in more than one list). An interesting exception is Jessica Mitford's (1963) classical account "The American Way of Death," whose witty criticism of how death's mystique in the US led to exorbitant prices in the funeral industry. I thank Eunice Yau for excellent research assistantship.
} 
hospice could save money and invoked the argument in every congressional hearing on the topic, at times citing anecdotal evidence from individual hospices that managed to save several thousands of dollars by cutting spending on invasive measures and days of hospitalization. ${ }^{7}$ In 1982, Congress voted to approve the hospice benefit, based on what two prominent researchers defined as "limited information," "case study reports," and "anecdotally based vignettes" (Mor \& Barnbaum, 1983).

Hospice was the only new Medicare benefit approved during Reagan's first administration at a time of great fiscal austerity. It passed because advocates convinced legislators that it would serve austerity. "The number of cosponsors on the hospice law," one NHO advocate commented, "went up dramatically when the Congressional Budget Office reported [...] [it] would save the Medicare system over a \$1.9 million over 5-year period." After Congress approved the benefit, the number of hospices and hospice patients began rising steadily (Fig. 3). The reliable new public funding, combined with the aging of the US population, made hospices attractive to for-profit corporations. By 2016, two thirds of the US hospice industry were for-profit and much of it provided high Return On Investment. Chemed Corporation, the company owning the country's largest hospice (Vitas), added some $315 \%$ to its share value in 2014 2019, about three times more than Apple and Google did during the same period. ${ }^{9}$

Disagreements over hospices' cost-saving potential continue to this day and have led researchers and organizations to conduct new cost-evaluations (Emanuel \& Emanuel, 1994). None of these studies were conclusive, yet they added up to a corpus of research that valuated end-of-life care monetarily, made the dollar price of life prolongation visible, and invited discussions on how to reduce it. As a professional movement, hospices topicalized the end of life and made it a realm of medical expertise (Broom, 2015). As political actors, the movement's advocates made this realm the center of financial discussions. Politicians, economists, and advocates who debated whether or not hospices could save money instituted a general understanding that the end of life was, potentially, an area where financial saving could and should be achieved.

The second group of actors who advanced the monetary valuation of care at the end of life were health economists who, beginning the early 1970 s, produced numerous expost evaluations of spending on patients who died. Such evaluations became possible after the passing of Medicare, which provided analysts with datasets of unprecedented quality and consistency on medical spending and utilization. In 1973, the Social Security Bulletin reported that Medicare's spending on "patients who died" was significantly higher than its spending on survivors (Piro \& Lutins, 1973). That year, health economist Joseph Civetta echoed this finding, writing that, in a Massachusetts ICU that he studied, "costs [...] seem to be inversely correlated with chances of survival" (Civetta, 1973). He clarified that this provocative statement was not causal, meaning that it was impossible to predict patients' survival based on how costly their treatment has been. ${ }^{10}$ Yet the subtext was clear: Medicare was disbursing enormous

\footnotetext{
${ }^{7}$ E.g. Statement of Dennis Rezendes, Subcommittee on Health, Committee on Ways and Means, House of Representatives, 6/18, 27/1979: P. 409.

${ }^{8}$ This negligible amount was close to budgetary neutrality, which in this case was sufficient. Statement of Rev. Hugh Westbrook, US House of Representatives, "Medicare in Florida: looking to the future," hearing before the select committee on aging, 98th Congress, 1st session, December 28, 1983, P. 77.

${ }^{9}$ Data are from Yahoo Finance.

${ }^{10}$ This point was recently corroborated using predictive modeling (Einav et al., 2018).
} 
amounts of money on failed treatments - as evidenced by the fact that the treatments' recipients died. By the late 1970s, health economists were warning that medical advent was financially unsustainable. "Those responsible for advancing medical frontiers," Cullen et al. wrote, "do not consider the financial impact of providing increasingly costly, high-quality intensive care on a large scale. [...] These costs are becoming intolerable and will be self-limiting" (Cullen et al., 1976, p. 986).

Similarly to the case of hospices' cost-saving potential, data supporting the assertion that spending on patients who ultimately died was excessive were equivocal (see Aldridge \& Kelley, 2015; Lubitz \& Riley, 1993; Riley \& Lubitz, 2010; Scitovsky, 1984, 1988). And still, as in the case of hospices, the scholarly controversy had the impact of establishing the end of life as an object of monetary valuation and costcontainment. The outcome reverberated in public discourse as a common wisdom, for example when Colorado Governor Richard Lumm declared that "we've got a duty to die and get out of the way with all our machines and artificial hearts and everything else like that and let the other society, our kids, build a reasonable life" (quoted in Scitovsky, 1988). This general understanding also impacted how hospitals, insurance companies, policymakers, and physicians thought about the end of life. In an interview, a hospital internist told me:

You know, there's always statistics: we spend like, you know, fifty sixty, seventy percent of our healthcare [costs] on the last two years of life, right? ${ }^{11}[\ldots]$ I feel things have to change because, you know, at some point we can't keep on spending this much money on health care. That's a fact. We're spending way too much money on health care and, when I look at it, I just feel like we waste money. [...] We're getting to the point where our healthcare is growing so much that we're gonna have to put a limit on it at some point, you know, it's just getting too much.

Health economists transformed the end of life into a discrete object characterized by inner regularities, which can be studied, known, and managed (cf. Mitchell, 2002). A 1997 Institute of Medicine report, which summarized much of the research in the area, included a long list of such regularities: "a small percentage of those who die each year account for a considerable percentage of total health care spending"; when extending the period analyzed beyond a year, the spending gap between deceased patients and survivors declines; compared to cancer diagnoses, chronic conditions such as diabetes and kidney failure lead to longer periods of high decedent-to-survivor spending ratios; Medicare spending on decedents drops as their age increases, while its spending on survivors increases as their age increases; and terminal illness has far-reaching financial consequences for families of decedents (IoM, 1997, pp. 156-159). The report also enumerated several potential methods that might help reduce end-of-life spending: increasing the use of advance directive forms, hospice, managed care, medical futility guidelines in hospitals, and various care-rationing mechanisms (IoM 1997). A year after the report's publication, the Open Society Institute convened a meeting on the economics and financing of end-of-life care, which among other topics, examined how financial incentives could be "redesigned to encourage death in one

\footnotetext{
${ }^{11}$ The actual figures are different: in 2011, $13 \%$ of the total healthcare spending and some $25 \%$ of Medicare spending was on people in the last year of their life (Aldridge \& Kelley, 2015; Einav et al., 2018).
} 
setting or another" (Clark, 2013, p. 160). Health economists' designs became an important tool in the management, handling, and economization of end-of-life care (cf. Griffen and Panofsky, forthcoming).

A third group of actors who fostered monetary economization in end-of-life care were palliative care advocates who, starting the late 1990s, worked to convince policymakers, insurance companies, and hospital administrations that cost saving through palliative care - prior to admission to hospice - was possible. A palliative care advocate who promoted the cause on the national level told me in an interview:

For sure, one by one, [we talk to] hospital administrators to make the case for palliative care. And one thing [our advocacy organization] has done very strategically is to think about $[\ldots]$ the evidence base necessary to demonstrate value for palliative care. [...] Looking at the financial impacts of palliative care services, which is really important. [...] To push it. You know, having a business model for palliative care has been a really important part of the growth. [...] Policymakers are also targets [...] [and] insurers are another target. [...] And there have been some good experiments by insurance companies out there.

Economizing the end of life monetarily was conducted here by implanting a pattern of calculative thinking toward end-of-life care in healthcare organizations. The advocates approached a variety of organizations (e.g. hospitals, state agencies, and insurers), encouraged them to look at their spending in the area, and argued that they could save costs if they adopted palliative care. In the 2010s, the Center to Advance Palliative Care (CAPC) began training palliative care clinicians on collecting data on the money they saved their hospitals through reducing the use of expensive life-prolonging measures (Pantilat et al., 2007; Warner \& Gualtieri-Reed, 2014). Practitioners could then show their administrations that their service would pay for itself by saving resources that would have otherwise been spent on keeping severely ill patients alive. A social worker in a palliative care service told me she was hired only after proving that she could save them money:

Palliative care [here] was [...] just doctors and didn't have a social worker. So I thought maybe I could be their social worker. The hospital always said they didn't have any money for that position. So I said, okay, I'll volunteer for you [...], but I [will also] look at length of stay in the hospital. Because if I can reduce length of stay, it will save the hospital money. [...] So it was actually a moneypiece [...], and of course, it was a no-brainer, because I cut down on the length of stay. [...] That's how I actually got the job.

The heads of six palliative care teams that I interviewed gave me mixed reports on how much their administrators cared about the financial savings that their service generated. Still, all but one of them collected data on such saving at some point in the service's history. ${ }^{12}$ An advocate who trained teams in collecting data on the cost saving they achieved told me:

\footnotetext{
12 The only service that did not report collecting such data was housed at a Veterans Affairs (VA) hospital. The VA system has a palliative care mandate since 2003, and physicians in the system do not depend on proving cost-effectiveness.
} 
I cannot think of a case where a team [I worked with] has run their financial analyses and it's disappointed. I think the much more common flaw is [when] a team doesn't look at their financial outcomes [...]. It's the issue of, what have you done to help your institution recognize the financial benefit of staffing your [palliative care] service? What have you done to help them see that they can afford to do palliative care? [...] I think that the need to quantify the financial benefit of palliative care will remain incredibly important $[\ldots]$.

A problem still stands, however. Different hospitals work on different business models; a safety-net hospital funded by fixed county budgets with little income from insurance companies has a different financial interest than a hospital that treats an insured patient population and generates income on a fee-for-service basis. For the latter, reducing intensive care and medical interventions may reduce income rather than save money. Furthermore, documenting hospital costs in the US is a fairly abstract undertaking. There is little correlation between the prices that hospitals charge formally and the ultimate amounts of money that insurers or patients pay them (Rosenthal, 2017), meaning that the cost of care for the hospital can be calculated in many different ways. When I asked an advocate about this, she responded:

You're right, [but] I'm not the one who has to answer that question: [...] I'm freed by the luxury of being able to have a very pragmatic focus. If I talk to somebody, [...] the only thing that matters is how they conceive a cost. (emphasis mine)

The goal of palliative care advocacy was persuasion: convincing administrators that their financial goal was reducing utilization within the hospital. Advocates created a phenomenology of cost saving, which supported the impression that palliative care was saving money. Documenting and visualizing expenditures on days of hospitalization, and then showing that palliative care clinicians reduced length of stay, was one way of creating such an impression. Another way was authoring reports such as "The Business Case for Palliative Care," which analyzed the financial interests of different hospital systems and explicated why palliative care services would serve all of them (Pantilat et al., 2007). This report maintained that the US was moving toward managed care and away from fee-for-service payment, predicting that hospitals would face pressures from insurance companies and regulators to reduce utilization. Palliative care would be an indispensable tool in this context, and an administration that opened a service early would have a long-term advantage.

The most explicit regime of valuation that hospice and palliative care advocates established drew on professional evaluation of what lives were worthy of living and a corollary judgment on what treatments were and were not valuable. Economization, however, also involved a regime of monetary valuation, whose origins can be found both inside and outside of hospice and palliative care circles. This monetary valuation did not infringe on the medical valuation. The two economization projects - medical and monetary - merged in an unlikely, albeit logical, convergence: on the one hand, a progressive mobilization with origins in anti-institutional and anti-medical sentiments during the 1960s (Eyal et al., 2010); on the other hand, a wave of fiscal conservatism that welcomed any opportunity to cut on public spending (Gong, 2019; Livne, 2014). 
Yet beyond this convergence, the pursuit of monetary saving itself acquired moral meaning. The people and organizations who promoted it did so not only because they saw it as serving their professional interests, but also because they believed it was an additional positive contribution that they could make to US healthcare - avoiding waste and channeling resources to alternative, beneficial, and more appropriate treatment. Terms such as "waste" and "beneficence," however, cannot exist outside of moral frameworks that define good and bad, proper and improper, valuable and counterproductive - which the hospice and palliative care movement was ready to provide.

Hospice and palliative care advocates did not abandon their initial orientation toward economization. Fostering prudence in the face of the abundant life-prolonging and lifesustaining interventions that modern medicine offers remained their core idea, but this economization was now entangled with monetary values. The regime of valuation that the economization of dying enacted expressed life, death, and dying in professional, as well as monetary terms. Evaluating the benefits of life-prolonging and life-sustaining treatments also meant evaluating the high spending on them, informing the enactment of financial and medical limits at the end of life.

\section{Patient centered valuation}

The third regime of valuation surrounding end-of-life care centered on patients. Starting in the 1960s, against the backdrop of the civil rights movement and the mobilization of patient advocates and ethicists, the individual patient assumed a pivotal role in medical decision-making. The principle of "patient autonomy" became the dominant doctrine in US bioethics, replacing more traditional approaches that based medical decisions on physicians' professional authority and what they judged to be patients' best interests. A new generation of clinicians was now expected to recognize the patient's right to weigh in on decisions, exercise sovereignty, and be free from external professional and institutional coercion (see Arney \& Bergen, 1984; Dworkin, 1993; Evans, 2002; R. C. Fox \& Swazey, 2008; Katz, 1984). Laws, declarations, and guidelines that passed in the following decades made it hard to treat patients without their consent and against their will. ${ }^{13}$ Beyond any formal statutory constraint, treating patients against their will and for their own good became morally questionable, even intolerable. Patients' choices, opinions, and preferences were now an ethical compass, a pillar of fire that guided clinicians through dilemmas and quandaries, granting value and legitimacy to certain courses of treatment and rendering others morally flawed and ethically misguided. The two regimes of medical and monetary valuation were combined with a third regime, in which patients were the main actors entitled to judge the worth of their life and the medical care used to prolong it: a life worth living was a life that a patient felt was worth living.

Authors and advocates in the field of end-of-life care expected that, if given the prerogative to influence medical decisions, severely ill patients would deem their lives meaningless, and life prolongation useless, and embrace hospice and palliative care's judgment that less is more near the end of life. In her best-selling and most influential book, "On Death and Dying," psychiatrist and hospice advocate Elisabeth Kübler Ross

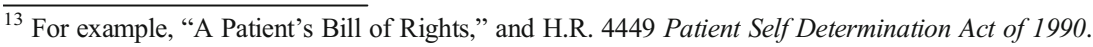


described the archetypical US dying patient lying in the hospital bed passively as "an object of great concern and great financial investment." Agonizing in pain, this patient "may cry for rest, peace, and dignity," but is nevertheless connected to life support and treated with innumerable invasive procedures. In the hospital's hustle and bustle, physicians and nurses are fixated on technical details: "heart rate, pulse, electrocardiogram of pulmonary functions, [...] secretions or excretions, but not with [the patient] as a human being." For this patient, medicine's "useless fight" is "merely a way to prolong agony," yet the professionally focused clinicians are oblivious to this sentiment (Kubler-Ross, 1969, pp. 22-23).

This description, and the expectation that once allowed to opinionate on the care they receive, patients would restrain medical maximalism, had some basis in reality. During the late 1960s, the same period that hospices developed, popular discourse in the US was filled with critical conversations about death and dying. Historian Peter Filene found that, from 1968 to 1973, the number of articles on the topic in masscirculation magazines doubled each year, then doubled again from 1973 to 1975 (Filene, 1998, p. 49). The same applied to books (see Fig. 4). ${ }^{14}$ Numerous memoirs by terminally ill patients and their survivors were published during the period (Filene, 1998, p. 49; see Bell, 1961; Hanlan, 1979; Scott Bermer, 1979; Smith, 1969; West, 1966, 1976), and so were critiques of the medicalization of death and the silencing and objectification of patients (Filene, 1998; Kubler-Ross, 1969; Mannes, 1974). No less intriguing were books with titles such as "To Die with Style" (McCoy, 1974), "Living Your Dying" (Keleman, 1975), "Learning to Die, Learning to Live" (Herhold, 1976), and even "It's Your Death... Make the Most of It" (Billnitzer, 1980)—which expressed and popularized very particular views on death and dying. Authors valorized the acceptance of death, presenting it as a moral virtue and a sign of one's strength of character: "I have come to believe it is possible for us to live into our deaths with energy and integrity," Marjory McCoy wrote. "It may not be possible to eliminate entirely the existential fear of that awesome Unknown, but I do believe we can consciously utilize the kind of trust and courage with which we face the many unknowns of life" (McCoy, 1974, pp. 14-15).

Dying while rejecting the abundant interventions that medicine offers became a cultural taste, which many people shared and voiced. ${ }^{15}$ Hospice advocates and authors on the topic attributed universality to this particular taste, calling this abstemious way of dying a "good death." This, however, was an exercise of symbolic violence (Bourdieu, 1979). The dying processes described as a "good death" represented the views and experiences of a particular social class: primarily highly educated, white, and middle to higher income people, who had access to healthcare throughout their lifetime and whose chief concern was a problem of excess, i.e. receiving too much treatment"surfeit," in Abbott's terms (2014). Rejecting extensive life-prolonging measures

\footnotetext{
${ }^{14}$ As the figure shows, from the mid-1980s and into the 1990s, authors largely replaced the term "death and dying" with "end of life." The level of writing on the topic, however, shot up in the early 1970s and has remained relatively stable since then.

${ }^{15}$ This stance, which emerged from autonomy principles and anti-medical sentiments also inspired the rightto-die movement and its campaigns to legalize euthanasia and physician-assisted suicide (Filene, 1998). Hospice and palliative care advocates very carefully distinguished themselves from this movement — some out of belief that life should not be actively terminated, others seeking to avoid controversy that would alienate religious people (Livne, 2019 ch. 3).
} 
resonated the most with these people, and they had the social power to make their subjective tastes and views objective by publishing widely-read memoirs, op-eds, and editorials.

Hospice and palliative care advocates further amplified these privileged voices. Beginning with the first hearings that Congress held on care for the dying in 1972, advocates brought terminal patients, family caregivers, and survivors of deceased patients to testify in Washington about their personal experiences. The unified patient voice in these hearings defied medical maximalism and embraced the abstemious approach, which dovetailed hospice ideas. During 1972-1990, twenty-nine people shared with Congressional committees narratives of their personal experiences with terminal illness or as caretakers of a terminally ill relative. ${ }^{16}$ In various ways, all of them said they preferred moderate and non-"aggressive" treatment at the end of life, and all of the witnesses who had experience with hospice described it in very positive terms. $^{17}$

There are indications, however, that other, uneconomized and maximalist voices existed but were not heard. A Pew survey conducted in 1990, 2005, and 2013 showed that a significant and growing proportion of Americans support the categorically maximalist stance that "in all circumstances, doctors and nurses should do everything possible to save the life of a patient." $31 \%$ of the respondents endorsed this statement in 2013, up from $15 \%$ in 1990. The percentage of people who agreed with the equivocal statement "sometimes [emphasis mine] there are circumstances where a patient should be allowed to die" declined from 73 to $66 \%$ during the same period (Pew Research Center, 2013). Support for the uneconomized maximalist statement was significantly higher among African American respondents (52\%), Latino respondents (59\%), and respondents without college education $(43 \%)$ compared to white respondents $(20 \%)$ and those with a college education (18\%). Unlike what Kübler Ross and hospice advocates assumed, the professional and financial economization of end-of-life care is gradually coming to collide with many patients' valuations of life and life-prolonging treatment. Patient autonomy has been central to this process, as it empowered many patients to demand that their lives be extended as much as possible. Alongside an extremely powerful medical-industrial complex — which inundates patients with information about new treatments, medications, and devices that promise miracles - autonomy provided fertile grounds not only for economization, but also for resistance to economization (Kaufman, 2015).

Within the hospice and palliative care regime, differences in stances on end-of-life care quickly transform into a hierarchy that reproduces social inequalities. White and highly educated people are more likely to valuate life in sync with the hospice and palliative care regime of valuation than people of color and those with lower levels of formal education. Conversely, people of color and those without a college education are at a higher risk of becoming "problem patients" in clinicians' eyes, because they are

\footnotetext{
${ }^{16}$ Two of the witnesses were known politicians: former Senator Jacob Javits and Representative Leon Panetta. I included both in the count since they testified on personal experiences, not their positions as lawmakers.

${ }^{17}$ For a list of Congressional Hearings see Appendix. Only in the late 1990s, when Congress began discussing the controversial topic of physician-assisted suicide (and later on, "the right to try" treatments that FDA has not yet approved), did patient advocates who supported life-sustaining treatment in severe illness appear in Congress. These testimonies indicated a progression of the conservative pro-life agenda into end-of-life discourse (Anspach, 2010) and also that patients interested in life-prolongation did exist, but were excluded from other hearings.
} 
more likely to embrace a categorical and maximalist position and decline any limit on life-prolongation (Hauschildt, 2020).

During fieldwork and in interviews, I heard many physicians recounting what they called "horror stories" about patients whose care became "a complete mess," because they or their family members insisted on resuming life-prolonging treatment and refused to economize. At times reluctantly, physicians described patients' ethnicity or "culture" as the reason behind maximalist stances, thereby Othering the patients. ${ }^{18}$ A general internist at a hospital told me:

I think harder situations are [...] ethnic or certain cultural beliefs that can make it very difficult. [Q: for example?] For example, sometimes what we view as suffering they [emphases mine] view as sort of a natural thing that one has to go through before death. I've had a few patients like that where I don't think there's a chance of meaningful recovery... Why are we doing this? And they're like, 'well, it's okay, it's something someone has to go through before they reach death.'

A nephrologist (kidney specialist) told me:

Some cultures revere the elderly, and it's sort of like they are the anchor among a family unit, and some cultures or ethnicities tend to stay in the same geographic region because that's their nature, that's what they do. [...] [So] the loss of the patriarch or matriarch can be [more] destabilizing [to] some families and ethnic backgrounds [...]. Sometimes I can go into a discussion on end-of-life issues and I'm good at predicting what the outcomes [will] be based on having met family members and knowing a little bit about them and their background. [...] Some ethnic groups, some religious affiliations. [Q: Who for example?] Oh, I don't know that I need to get specific, but you'll just have to trust me on that [Both $\operatorname{laugh}^{19}$ ].

A palliative care physician was more blunt and direct:

Well, it's an easy conversation to have with these very literate smart people. [...] [After a good meeting with a family,] I said, "Gosh, that was what life would be like if all I did was take care of über-literate aristocratic white griffons. You know what I mean? We're horribly politically incorrect in our team. We're just completely bigoted and awful. I take care of a lot of Chinese patients at the hospital. They're hard, man! [Q: Russian Jews. ${ }^{20}$ ] Russian Jews are BRUTAL. They're fucking hard. I mean, go back far enough and I'm Russian Jew. [...] The Chinese are VERY hard. The Koreans are BRUTAL. [...] South Asian

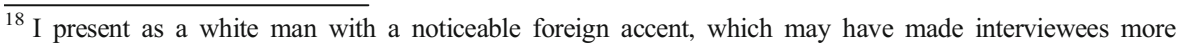
comfortable voicing stereotypical thinking and violating norms of political correctness that they followed when talking to a US born interviewer or a person of color.

19 The laughter was indicative. The physician laughed because my direct question made him understand that I thought his thinking was stereotypical and wanted to have him develop it on record. I quickly joined him because I understood that he understood.

${ }^{20} \mathrm{I}$ had heard references to Russian Jews during my fieldwork and in other interviews.
} 
patients - Indian, Pakistani- $[\ldots]$ of the ten or fifteen cases I probably had, probably seven or eight of them have turned into a HORRIBLE [...] mess. [...] I'm speaking totally in generalities, because the individual patient [...], every once in a while you'll get a Chinese family coming in and saying, "We just don't want mom to suffer. We want her to be [in] hospice." And you're like, "What happened?" You were preparing for the battle of the three dragons, and the next thing you know is like, "Wow, that was easy." [But with a son of a Russian Jewish patient,] he didn't want to accept hospice and doesn't want to accept the shitty nursing home that Medicaid would pay for. So finally, I feel like grabbing him, you know, and just "arrrrgh!"

Clinicians spoke more freely of such patients' social backgrounds when referring to immigrants from relatively privileged countries, but I noticed they had similar views on African American and Latino people, which they hesitated to share in interviews. When they did, interviewees quickly tried to explain empathetically what they considered as ethnic and racial differences. An explanation I heard several times was that African Americans were likely to insist on continuing life-prolongation against physicians' advice because of mistrust in medicine and the healthcare system. The demographic composition of the three palliative care services I studied in-depth was not conducive to interracial trust-building: all but one of the clinicians in them were Caucasian. ${ }^{21}$ Still, with few exceptions (e.g. a chaplain who suggested that her all-white team may have alienated an African American family), the clinicians described mistrust as a property of African Americans, not a relational outcome of contact between all-white medical teams and a patient (or family) of color.

Consider one revealing case. The Intensive Care Unit (ICU) physicians of a public, safety-net hospital consulted its palliative care service on the case of a young African American patient, who had suffered a heart attack and was connected to a ventilator in a condition they defined as 'close to brain dead. ${ }^{22}$ The man's sister and stepsister were very involved with his care and visited the hospital regularly. In a team meeting, a palliative care physician noted that the ICU team reported 'difficult' interactions with the sisters and mentioned that they 'wanted to ensure that he gets the maximum care possible.' In her first meeting with the palliative care physician, one sister expressed frustration with an ICU physician, saying that when she came to visit her brother this physician took her aside and talked to her about 'pulling the plug on him' before she even put on the gown. Later on, the sister told the palliative care team's chaplain about two relatives whom doctors had given 'no chance,' and yet one of them was still living 'almost independently.'

At a later palliative care team meeting, the physician spoke about her meeting with the sister. She told the sister that the patient was not feeling any pain, and then added that medical interventions may make him uncomfortable. The sister challenged her: 'if you've just said he's not feeling any pain - how is it possible that interventions would make him uncomfortable?', to which the physician responded: 'we don't know what he feels and doesn't feel, but I always take interventions as inherently uncomfortable.' The

\footnotetext{
${ }^{21}$ The one exception was a white-looking immigrant from Venezuela; she was a social worker of middle class background who moved to the US and naturalized after marrying a US citizen.

${ }^{22}$ I use single quotation marks whenever a text is taken from my fieldnotes or paraphrased and double quotation marks whenever it is transcribed verbatim from an audio recording.
} 
physician promised the sister that she would keep seeing the patient and would also make sure that the nurses played his favorite music in the room. They scheduled a follow-up phone call for the next day.

This call did not start well. While she was waiting for the phone to ring, the physician made a 'quick couple of calls to organize different things' for the patient, and the sister was transferred to the automated voice messaging system. In the message she left, the sister noted the physician had violated a promise - 'well, you told me you'd wait by the phone...' - and the physician called back immediately to explain, somewhat defensively, 'I was making a few calls for your brother and the [phone's] light didn't go on.' This difficult start notwithstanding, by the end of the conversation the sister said that the family was united in not wanting her brother to be in a vegetative state, and the stepsister added it was very helpful that 'I felt you talked about him as if he was your own dad.'

The team saw this outcome - an initially suspicious and resistant family voluntarily relinquishing life-prolongation - as a success. The family's view of the case now aligned with the team's and the hospital's views. I attended several team meetings and witnessed several interactions outside of meetings where team members discussed this case; other than a brief formal mention at morning team meetings (e.g. 'Mr. Smith is a 57-year-old African American man'), the patient's race was never explicitly mentioned or discussed. Yet, at the end of the last meeting, after the physician informed everyone that the family decided to remove the patient from life support, the team's chaplain asked if the 'race card [sic] played a role in any way here.' The physician agreed, noting that she thought African American families were, on average, more suspicious of the medical establishment and that there are other ethnic minorities that are similar, such as Russian immigrants.

Withdrawing or withholding life-sustaining care is a difficult decision with very high stakes, which is likely to involve long interactions between families and the medical staff. The sisters' past experience with a family member who survived after clinicians gave up on him compounded their negative experience of an ICU physician who too quickly broached the possibility of disconnecting their brother from the ventilator. In all likelihood, the palliative care team's all-white racial composition extended the leap of faith required from the sisters to enter any discussion of economization. Their marginalization in the case was multi-dimensional. First, the medical staff looked at the sisters and the patient as racialized Others - people with qualities that differed from a certain imagined norm, who required special attention and "cultural skills." The clinicians treated a relational phenomenon - the chasm between an all-white medical team and an African American family — as a race-specific quality: mistrust that African Americans in general, hence this family in particular, feel. Second, from the palliative care perspective, the initial position that the sisters embraced - refusal to engage in any decision on economizationwas branded as misguided, irrational, and immoral: it made little sense to clinicians that a patient who was "nearly brain dead" would be kept on life-support. Within the regime of valuation that palliative care advanced, such families were discounted, and minoritized populations had a higher likelihood to be among them.

\section{Economized selves}

Although palliative care clinicians tended to value abstemious medicine at the end of life, they were also inclined to follow patient autonomy principles and prolong life 
when convinced this was what their patients wanted. Ethnographers of medicine have shown that clinicians do not adhere to autonomy principles at all times and are especially likely to discount the patient and follow their own judgment when treating the poor, the socially marginalized, and the patients they perceive as having low "social worth" (Anspach, 1993; Heimer \& Staffen, 1998; Sudnow, 1967). In my own fieldwork, however, I found that even when clinicians fully followed autonomy principles and refrained from imposing their values on patients, marginalized patients were still at a disadvantage within palliative care's regime of valuation.

The source of this disadvantage has less to do with outright discrimination toward certain social groups. Rather, it is largely rooted in inequalities that are structured into patient autonomy's premises and the methods that clinicians use when garnering patients' values. The premises of patient autonomy are fundamentally liberal (Gong, 2017). First, autonomists tend to conceive of patients as aware and reflective individual actors, who are able to formulate opinions and make choices when given the appropriate tools, information, and prerogatives (Friedman, 1990). Second and more fundamentally, autonomy principles draw on the view that human action originated from an inner-core, with a certain degree of coherence and stability, which people call "mind," "personhood," or "self."

Both premises are key to how palliative care clinicians interact with patients. The way they see it, palliative care clinicians' task is not understanding what a certain patient wants at a given moment, but rather mapping out this patient's inner-being - her or his defining traits, as opposed to more temporary desires, moods, and impulses. Palliative care clinicians' question is therefore not what the patient wants, but who the patient is (Foucault, 2005).

Answering this question is a complex process, riddled with contradictions. For one thing, as Bernard Lahire observed, ascribing stability, essentiality, and consistency to human agency is an abstracting act. It means affixing vicissitude by reducing the plurality of actions, predispositions, caprices, and idiosyncratic tendencies that comprise human agency into a single, unified personhood. This reduction is commonplace, and not only in the medical setting: social security numbers, first and last names, awards and honors, and penal systems that hold people accountable for crimes they committed decades earlier make up a social order that defines and thereby configures people as coherent and singular actors (Lahire, 2011). In US healthcare, the spread and influence of patient autonomy principles has made it institutionally necessary to treat patients as such singular actors. Once patients' judgment and valuation came to indicate how physicians should treat them, clinicians needed - and therefore demanded and incited-patients to express themselves and make their agency manifest coherently, so that it could inform decision-making (Arney \& Bergen, 1984, p. 194).

The movement for hospice and palliative care has made extensive efforts to socialize people to be opinionated, expressive, and consistent decision-makers as patients. Beginning in the 1990s, the Robert Wood Johnson Foundation (RWJF), Open Society Institute (OSI), and other funders supported several projects that trained the public at large in formulating personal end-of-life preferences. RWJF's "Last Acts" campaign worked with journalists, authors, reporters, documentarians, television and radio producers, and newsletter and industry publication editors "to encourage their participation in addressing the culture and experience of dying in America." One of the campaign's most famous outcomes was Bill Moyers' PBS documentary series On Our Own Terms: 
Moyers on Dying, which aired in 2000 and had an estimated audience of 19 million people (Clark, 2013, pp. 59-60). An extensive network of 70 national civil society organizations collaborated with local T.V. stations to facilitate and coordinate public discussion on the series, which also drew much coverage in national newspapers and magazines. Barnes and Noble featured the program on its website and offered its customers a selection of books on end-of-life care in 900 stores. Local "coalitions" on end-of-life care held over three hundred town hall meetings and public discussion forums about the series (Clark, 2013, pp. 73-74).

Many other projects targeted smaller populations on a more local level. Physician Ira Byock transformed the small city of Missoula, Montana into a laboratory for an ambitious demonstration project on end-of-life care called the Montana Demonstration Project (MDP). He and his team surveyed and followed 250 families that experienced death over the course of one year, collecting data on how the area's various healthcare institutions cared for dying people. In the following decade, MDP continued to engage Missoula's residents in discussions about "individual and community goals" (MDP, 2013) on end-oflife care, attempting to "raise public expectations for improved end-of-life care" (Clark, 2013, p. 71). The project emphasized individual patients' self-determination, clarifying that it "does not advance any specific vision for a 'good death' or any agenda regarding the 'right way' to die or grieve" (Byock \& Merriman, 1998; MDP, 2013, n.d.).

Advocacy groups in over 200 localities embraced MDP's methods and conducted similar projects in their area (MDP, 2004). Researchers from the Vermont Ethics Network gathered 388 Vermont residents in 42 focus groups, asking them about their experiences with "end-of-life care for someone they knew intimately." A report they published summarized these residents' answers in nine concise statements, all written in first person plural, which ostensibly expressed public expectations of medical personnel who treated severely ill and dying patients. These statements represented patients as sovereign, agentic, and proactive, ending with the proclamation: "we hope our caregivers never forget that we are all unique individuals; that no generality applies easily to any of us" (Golodetz, 1997). Patients became people who wanted to know, make choices, and have themselves recognized as "unique individuals."

Such initiatives mobilized wide populations to participate in economizing as valuating actors, who reflect and produce valuations of their lives, communicate them to clinicians, and demand that the clinicians follow them. Advocates of palliative care appealed to the general public as a future patient population and encouraged them to have tastes and opinions on how they should be treated prior to their death. One of them told me in an interview:

[We are] trying to create demand for services. I think about it the way I think about birth. If you look at the way people were born in the sixties in America - it was very medicalized. And now - not because doctors and nurses thought it should change, but because patients thought it should change - you have birthing suites, what music you want, the Jacuzzi tub... [Author: dolphins!] Dolphins [laughs], and the rooms are really pretty... There's this change driven by patients. $[\ldots]$ The same thing could happen around the end of life, and it could be driven by families who say "we don't want someone tied up to machines, unconscious, in the ICU to spend their final days. What we want is to be home, to be at peace, surrounded by our family members - and what are you gonna do to make that happen and do you have the resources to make us achieve that? 
We don't see that yet. But you can imagine things moving in that direction. In some ways, that could be the most potent driver-if patients start choosing their hospital, their doctor by access to palliative care advocates sought to create popular tastes for palliative care. [emphases mine]

A good illustration of this approach is the initiative Reimagine End of Life Care, which began holding periodic citywide events in San Francisco and New York in 2016. These events feature an eclectic lineup of workshops, conversation circles, expert panels, art exhibits, and spiritual gatherings that relate in various ways to end-of-life care. They invite both young and old participants to learn how to fill out advance directive forms, have conversations about death with relatives, think about life's finitude, ponder the meaning they find in life, and find ways to translate these thoughts into organized lists of expectations, which they could later present to physicians.

The people participating in these events become active and voluntary subjects of economization at the end-of-life. Yet it is also clear that the populations most likely to attend such events have also been those most likely to economize in the first place: highly educated, mostly white, and liberal-leaning people, who live in the two most expensive cities in the country and think about end-of-life care as a consumers' lifestyle choice. When successfully mobilized to economize, these people become relatively close to the liberal agency that the patient autonomy approach imagines: they have coherent and clearly ordered sets of values, which inform their choices. They can be, so to speak, economized subjects whose subjective inclinations and styles of reasoning correspond to the expectations of the healthcare system that treats them.

By contrast, socially marginalized patients are more likely to stand in contradiction to autonomy's liberal assumptions. The challenge here is not necessarily that they would refuse to withdraw life-prolonging care, but that they would not formulate and exhibit any clear and consistent values regarding end-of-life care. A palliative care physician who worked at a public, safety-net hospital told me:

We have a lot of people in this hospital who have not planned in advance for anything. Ever. And that's why they're in the situations that they're in. And they may have used substances, or things that are not healthy that they don't have access to now in the hospital to cope with them. I mean, someone who has been drunk, kind of perpetually, for years and years and years, who now is in the hospital, totally sober, and is facing down this decision... [Physicians] want to come in and say, "what do you want your final days to look like?" And [the patient is] just a total deer in the headlights.

Physicians referred to such patients as "having no insight into their condition." Beyond loss of consciousness and capacity (which is very common in terminal illness ${ }^{23}$ ) these patients defied the institutional expectation that they behave as responsible and sovereign actors (Heimer \& Staffen, 1998). They "have not planned in advance for

\footnotetext{
${ }^{23}$ In US ICUs, estimates are that $96-97 \%$ of decisions to withdraw or uphold life-prolongation are made by agents other than the patient, mainly because the patient is unable to participate in these decisions. In the general population, some $70 \%$ of Americans over sixty whose care involve end-of-life decisions lack the capacity to make them (Shapiro, 2019, p. 7)
} 
anything," did not leave an advance directive or living will, and did not communicate clearly with the clinicians. Some of them lived an inconsistent and erratic life that did not lend itself to sweeping generalizations about their self or their subjectivity.

When patients defied the expectation to present an accessible and relatively stable self with intelligible preferences and values, clinicians used techniques and tools to make patients' subjectivities manifest nevertheless. These means of production of subjectivity could make patients cough out valuations, even when they were initially disinclined to do so. Most commonly, clinicians followed the principle of "substituted judgment" and asked patients' relatives (or other acquaintances) if the patients had ever expressed any stance on end-of-life care (Shapiro, 2019). Patients who had relatives or friends who knew them well, had talked to them about the topic, and were able to reach an agreement over what the patient would say if they were able to speak could present a more solid and undisputed personhood for the patient, in these cases.

When these conditions were not met (e.g. when patients had no relations who knew and were comfortable representing them), clinicians resorted to other means. One of them, which I saw being used in two of the three services I shadowed, was a card game called "Go-Wish." 24 Go-Wish included dozens of cards with end-of-life wishes printed on them, and palliative care clinicians asked their patients to sort these cards into three piles: "very important," "sort of important," and "not so important or unimportant to me." The patient was then instructed to choose the ten most important statements from the "very important" pile and rank them by order of importance. Among other statements, the cards included: "to maintain my dignity," "to be kept clean," "to say goodbye to people in my life," "not dying alone," "to be mentally aware," "to have my family with me," "to be at home," and "not being connected to machines." 25 The activity's outcome - various statements on end-of-life care that the patient rankedwere treated as reflective of how the patient valued her or his life: what they found most meaningful in life, what life-activities they would prioritize, and what qualified as a meaningful life to them in general. Specifying what one found valuable in life meant placing a limit on life's value, hence placing a limit on life-prolongation. The moment a patient recognized a certain life experience as valuable, the loss of this experience became the limit beyond which life had no meaning. For example, this was how a nurse reported to a palliative care team on a Go-Wish conversation she had had with a patient:

'Being free of pain was clearly the number-one important thing for him, and he said he was okay with that even if it'd make him drowsy. He would be okay with being kept on machines, as long as he can speak with his mom. If he's in a situation in which he cannot speak with his mom, he wouldn't want to be kept on machines.'

Once the patient declared that he valued 'being able to speak with my mother,' a limit was set: his life would lose value and should not be prolonged if he became unable to speak to her. Even when patients were not fully cooperative, clinicians thought the

\footnotetext{
${ }^{24}$ Go-wish was designed by a Silicon Valley nonprofit, run by people from "local hospices, hospitals, faith communities, universities, and elder care organizations". http://www.gowish.org (Last Accessed: June 18, 2020)

${ }^{25}$ These statements are based on a survey of patients, family members, and clinicians, which was reported in the Journal of the American Medical Association in 2000 (Steinhauser et al., 2000).
} 
activity had the benefit of training patients in thinking about what they wanted and providing even a vague indication of how they were thinking:

Things like [Go-Wish] can spark ideas. You know, not everyone is really able to fully engage and do this, but we do this on a fairly regular basis. We sit down with people and try to go through these, and get a better sense... ${ }^{26}$ A lot of times, it's not even just the sorting, it's the conversation that happens while they're reading it.

At the same time, similarly to advance directives and group discussions about death, the people most likely to engage in Go-Wish were those with highly valued cultural capital. When I interviewed this last physician, she told me she presented Go-Wish to the hospital's cancer support group, where people received it with much enthusiasm. I noticed, however, that other patients she was treating were completely disengaged. Several months after this interview, this physician sent me and a social worker to play Go-Wish with a patient who had terminal cancer:

\begin{abstract}
As it turns out, Dr. Evans asked Denise [Social Worker] to do it [play Go-Wish] with the patient a few days ago, and she did - but then the patient lost [the paper with the record of his wish ranking]. [...] As we walk, I tell Denise that I'm surprised she managed to do the Go-Wish with him. I saw the patient a few days earlier and he wasn't extremely communicative. She agrees and says, 'yes, I also think that he forgets a lot. It's possible that the Go-Wish form that we filled out together is in the trash. He doesn't really remember what he did with it.'

We go to his room. [The patient] doesn't seem alert, hardly engages in conversation, and eventually Denise decides not to repeat the Go-Wish activity with him.
\end{abstract}

Failures or outright refusals to play Go-Wish were common among alert and conversational patients as well. Many patients conducted themselves in a fluid, inconsistent, and variable manner, refrained from planning ahead, and tackled problems as they came along. As Susan Shapiro observed, actual severe illness trajectories are unpredictable and people change decisions and the ways they make them as circumstances change (Shapiro, 2019). Yet, even in this realm of unpredictability, the institutional expectation is that people exhibit some degree of consistent agency, fill out an Advance Directive, engage in conversation, or at least produce and endorse a hierarchical list of values through activities such as Go-Wish.

The impetus to constitute patients as valuating actors has been so foundational to palliative care work that several ethicists working in the area are now advocating to impute valuation patterns into incapacitated patients, based on these patients' sociodemographic characteristics. Annette Rid and David Wendler's Patient Preference Predictor would draw on surveys of various demographic groups' positions on endof-life care, then assign values to incapacitated patients based on their age, education, gender, race, ethnicity, and place of birth. Rid and Wendler contend that this method

\footnotetext{
${ }^{26}$ The plural pronoun "we" is misleading: in all of the cases that I observed, the Go-Wish activity was carried out by nurses, social workers, or lower ranked doctors (interns and residents) and medical students.
} 
would be far more "accurate" than existing practices of substituted judgment, since socio-demographic qualities are better predictors of patients' values than their family members' reports (Rid, 2014; Rid \& Wendler, 2014a, 2014b). This reveals just how fundamental liberal premises are to discussions in the area and how far those working in the area can go in generating sets of values that could count, even abstractly, as representing patients. Rid and Wendler surmise that all people have "values" and the challenge of clinicians (and ethicists) is to represent them accurately, even as they completely reduce patients' alleged values to their socio-demographic groups.

The patient-centered regime of valuation operated on two levels. On the one hand, it cultivated in people a capacity to choose, opinionate, and act in the realm of end-of-life care. Focus groups, discussion circles, best-selling memoires, TV shows, and public events that popularized the use of advance directive forms were concerted efforts to make people active and capable valuators of care at the end of life. On the other hand, while maintaining that there are many possible values that people may hold, hospice and palliative care advocates have also promoted certain popular tastes for end-of-life care, which rejected abundance and embraced a controlled, abstemious stance. The valuation of those who adopted this stance cohered with the two other regimes of valuation.

Like in the first two regimes of valuation, economization through patient-centered valuation operated not through imposing external limits on medical utilization, but by scrutinizing, pervading, and informing patients' judgment and capacity to valuate life and medical care. Because the third regime of valuation centers on individual patients' subjectivity, it produces comparably divergent valuations. Yet this divergence has regularities, which also enact hierarchies within the end-of-life economy. First, privileged populations are more likely to embrace the abstemious stances that correlate with end-of-life care's two other regimes of valuation. These populations' subjective tastes mirror the "less is more" pattern of valuation that defines the field, which accounts for one source of hierarchy within the end-of-life care economy: the subjective tastes and experiences of privileged populations have come to define what a "good death" means. Second, privileged populations are far more likely to exhibit agency that matches the liberal assumptions of patient autonomy. Their access to healthcare and resources such as advance directives, public events, focus groups, and medical teams that acknowledge them and discuss their preferences at the bedside means better access to formulating, documenting, and voicing intelligible values that clinicians can then recognize.

\section{Conclusion}

This article takes the effort to control, cap, and contain medicine's ambition to prolong life and defeat disease as indicative of a historical period, in which modern societies take on delineating the limits of progress and human capacity. I propose the term economization as helpful in analyzing how people and institutions mobilize to enact such limits. As defined here, economization means the establishment of a regime of valuation, i.e. the institutionalization of shared patterns of value attribution in a certain domain. I have identified three interwoven parts of this regime of valuation, which comprise the economization of end-of-life care. The first is the medical regime that 
hospice and palliative care advocates have promoted, which contends that when it comes to end-of-life care, less treatment is oftentimes more valuable. The second is a monetary regime that valuates the end-of-life financially and induces hospitals, insurers, and policymakers to conduct themselves more frugally and consider limiting interventions based on financial calculus. The third is a patient-focused regime, which designates the individual patient as an authority whose personality and values legitimize (or delegitimize) the prolongation of her or his life, and then mobilizes large populations to ascribe value to life in different conditions and, by extension, to the care that sustains it. These three regimes of valuation coalesce into an overall restraining force in US healthcare, whose focus is not on transcending death and going beyond current medical capacities, but on embracing and accepting mortality as an objective limit on human existence. This means defying a very basic modernist ambition to progress beyond the given.

This article does not seek to determine which of the three regimes-professional, monetary, or patient-focused-has been the most dominant or influential. For one thing, these three regimes have not always been competing. At certain historical moments - for example, when advocates presented hospice to policymakers as both cheaper and morally superior - they were complementary. Opposite situations, in which tensions between the different regimes arise, are abundant as well-for example, cases where severely-ill patients (or their families) pursue maximal life prolongation against palliative care physicians' best professional and moral judgements, and against the financial interests of insurers and sometimes hospitals.

Yet even such cases do not lend themselves to a straightforward determination on which regime is more influential. Different regimes were more central than others in different contexts, and palliative care clinicians drew pragmatically on one or more of them, according to the situation. Telling the children of a severely ill patient that they should withdraw life-prolonging care because it is too expensive, or informing a hospital's Chief Financial Officer that all life would be prolonged, regardless of costs, for as long as a patient (or a family) wanted, would achieve little more than conflict. Instead, palliative care clinicians might mention, for example, a patient's expressed wishes to a family member, this patient's grim prognosis to a fellow physician, and the high cost of treatment to an administrator. The economization of end-of-life care in the US allowed actors to selectively draw on the coexisting parts of the regime, without having to determine which one was paramount.

It is worthwhile, however, to reflect on the relative (and relational) role of the professional, monetary, and patient-focused valuations as drivers of historical change. Economy had been a noteworthy value in medicine long before the modern hospice and palliative care movement developed. Physicians assumed a dominant presence by the deathbed as early as the nineteenth century, and the goal they embraced at that time-facilitating good deaths by "assisting dying patients in their last hours, short of hasting death" (Lavi, 2005, p. 6) -all but mirrored the self-restraint that modern hospices propagated a century later. The innovative contribution of modern hospice and palliative care did not lie in professional and moral principles per se, but in these principles' systematization: their formulation as an organized body of professional knowledge, stamped by a formal certification process, and promoted by a developed network of advocacy organizations. 
It is hard to see how this systematization would have occurred had it not been for the two other components of the economization processes, which made up a political opportunity structure (cf. McAdam, 1996): first, the aftermath of the patient rights movement, which reoriented medical decision making to focus on patients; second, an unholy and somewhat unlikely alliance between the fiscal conservatism of the Reaganite right and an effort from left and center to somehow control the expansion of the medical-industrial complex and curb healthcare expenditure. Economy as a principle of medical care transformed from a private and individual practice of doctors at the bedside into a major professional, moral, and political movement, because the approach's advocates understood, adapted to, and capitalized on the political opportunities of the period. These opportunities, in turn, affected the movement and the specific ways that the end of life is currently being economized in the US.

Three characteristics of economization processes in general manifest in the case of US end-of-life care. First, by generating monetary, professional, and patient-focused valuations of life, the economization of end-of-life care has somewhat bound and moderated an otherwise categorical pursuit of life prolongation. Once patients, professionals, and administrators engage in defining what counts as a meaningful and valuable life, they also make determinations on when this life is meaningless and when its prolongation should therefore stop. Second, the economization of end-of-life care has been a hierarchical process, which elevated certain moral views and marginalized others. Hospice and palliative care emerged around the experience of upper and middle class people, whose major concern with healthcare has been excess. The rejection of aggressive life prolongation, which largely came from these circles, was a socially specific moral sentiment that the movement attempted to universalize. It was these upper and middle class populations that the economization of end-of-life care mobilized most successfully, as they were the ones who filled out advance directive orders and generated rankings of end-of-life preferences and values. Their advantageous social position meant that they were able to define what a "good death" meant in general and also establish an economy that would help them pursue these definitions. Lastly, the economization of end-of-life care informed and influenced the actions of patients, clinicians, and organizations that began valuating life and medical care in new patterns and methods. It changed how clinicians approached and treated cases of severe illness, how hospitals evaluated the organizational and financial challenges these cases posed, and how individual patients contemplated the value and meaning of their own lives.

Beyond the specific area of death, dying, and end-of-life care, this dynamic is reflective of a general challenge, which is particularly relevant to a period when the promise of advent and growth is doubted to the point of making them appear as problems no less than solutions. Consider the climate crisis. It is possible to think of further progress as a solution to this crisis: the progressive 2019 Green New Deal proposal, for example, deliberately called for "national, social, and industrial mobilization on a scale not seen since World War II and the New Deal Era," which would foster the development of new green technologies and also pull the US out of the social and economic stagnation it has experienced since the 1970 s. $^{27}$ Yet ultimately, what prescribes the direction of this mobilization are inflexible environmental and temporal

${ }^{27}$ H.R. 109. "Recognizing the Duty of the Federal Government to Create a Green New Deal." 116th Congress, 1st Session. February 7, 2019. 
limits, delineated and collectively recognized in a social process. The Club of Rome's 1971 declaration was an early indication of this dynamic: "If the present growth trends in world population, industrialization, pollution, food production, and resource depletion continue unchanged, the limits to growth on this planet will be reached sometime within the next hundred years" (Meadows et al., 1971). To this day, efforts to address the climate crisis take the form of determining "planetary boundaries" that economic, population, and other forms of growth should not exceed (Rockström et al., 2009), maximum average temperatures and carbon levels that humanity should not surpass, and time frames for the world to reach carbon neutrality (IPCC, 2018). The goal is not transcending upper limits, but identifying and enforcing them, i.e., restraining the modern growth trajectory before the Weberian moment arrives and "the last ton of fossil fuel has been consumed" (Weber, 2011, pp. 120-121). From this point in history, the future promises stagnation in the best case scenario and a regressive series of losses in the more likely one (Elliott, 2018).

In the same vein, consider progressive politics. The most basic attribute of progressive politics has been envisioning ideas that differ from present states of affairs and mobilizing people to make them a reality. In some circles, this politics is still alive, as evident in the World Social Forum's declaration that "Another World is Possible" (Fisher \& Ponniah, 2015) and in Erik Wright's call for a sociology of real utopias (Wright, 2010). Yet, as Wright himself acknowledged, this type of utopian thinking has been in decline for decades - to the point that utopianism has become synonymous with impractical and unrealistic politics. Claus Offe suggested that the most central progressive mobilizations today do not pursue futures that differ from the present, but defend and preserve already-won victories and states of being. Campaigns to "keep abortion legal," "defend affirmative action," "protect public education," bring taxation back to its 1960s levels, and protect the environment do not imagine alternative futures, but seek to preserve the present by putting "stop signs" in the way of reactionary and regressive shifts (Offe, 2019).

Consider economic growth. Pursuing high growth rates has long been a panacea for social and political problems - a way to sideline debates over distributive justice (how to divide the pie) with a promise to grow the entire pie for everyone's benefit. This framework, however, has weakened over the past half century (D'Alisa et al., 2015). For one thing, many economists have grown doubtful about the feasibility of continued high growth. Robert Gordon argued that high growth in the US was restricted to a single century (1870-1970) and is attributable to three industrial revolutions whose fruits have largely been exhausted (Gordon, 2016; Piketty, 2014). Fred Hirsch suggested that once societies reach a certain level of wealth, individual success starts depending on one's advantageous positioning vis-à-vis others, making economic life a zero-sum game where individual achievement does not promote societal growth (Hirsch, 1978). The persistent failure of developed countries to produce high growth despite historically low interest rates speaks to the relevance of these and similar analyses today.

Such stagnation of economic and social progress is discernable in people's subjective, existential experiences as well. When Sherry Ortner conducted interviews with her class of 1958 classmates, she noted how central "success" was in their life-narratives. This class graduated a year after the "Happy Days cohort," which Hauser studied (Hauser n.d.); they came of age in an era of expansion and defined themselves through 
the experience of going beyond their original class disposition (Ortner, 2003). Compare this to the existential condition of millennials, who are predicted to be the first generation to earn less than their parents and whose chances of upward mobilization have declined to a mere 50\% toss-up (Chetty et al., 2017). The so-called millennial condition is defined by a struggle to preserve, not exceed, one's class disposition - to make do and hang onto the property and wealth that one's parents pass on (Lambek, 2015, p. 14; Zaloom, 2019).

I make two propositions related to such situations. First, I suggest that sociologists should take such limits as outcomes of a social process, in which various actors make claims regarding the objectivity of certain limits and try to persuade others of the necessity to adjust policy, modes of governance, and human behavior accordingly. Claims for limits on progress should not be taken at face value. At certain times and by certain people, such claims may be endorsed as unquestionable truths, but in other cases they may be accepted as avertable or artificial problems. Consider, for example, Stanley Jevons's warning that the depletion of coal mines in the United Kingdom could bring the country's economic progress to a halt (Jevons, 1866), and Paul Ehrlich's ominous prediction that population explosion would crowd out the planet's space and resources (Ehrlich, 1968). On hindsight, both claims can easily be dismissed - although the threat of the population bomb, which demographers largely agree has been exaggerated, still lurks behind the current environmental crisis (Lam, 2011). Yet at the time they were made, these claims referred to pertinent problems, which could be dismissed offhandedly only by adopting a metaphysical view of progress and asserting that human ingenuity and innovation would always surpass all limits and obstacles (Simon, 1996). Like past claims on progress's limits, current predictions about environmental, economic, and scientific limits can be dismissed by resorting to general faith in progress, growth, and opportunity. Yet, as this article shows, alongside them we can also find widespread mobilizations and stances that revolve around the recognition of limits and the effort to enforce them: alongside growth in utilization and spending on life-prolonging care and medical technologies, we can see a rise in attempts to limit this growth; alongside the promise of economic opportunity and growth, we can find calls to focus on reallocating existing resources (Fitzpatrick, 2004); and alongside denials of global warming and blind faith in future and yet-to-be-invented technologies to solve the climate crisis, we see extensive (though so far failed) attempts to abide by environmental limits, reduce consumption, control production, and govern carbon emissions.

My second proposition is that curbing growth trajectories hinges on the promotion of new regimes of valuation and, therefore, the concept of economization as defined and used here can be fruitful in analyzing the enactment of limits on growth. On the one hand, determinations of value are also determinations of finitude. Financial valuations of the environment (Fourcade, 2011), as alternative valuations of national wealth that take environmental degradation into account (Constanza et al., 2014), ascribe worth to the environment and by that bind and define what was previously indefinite. These and other valuation projects can mobilize people and institutions - for example, by developing tastes for environmentally friendly goods (Elliott, 2013), adopting abstemious lifestyles that reject the riches of capitalism (Barnard, 2016), or promoting environmental valuation schemes in rational calculations (MacKenzie, 2013). On the other hand, recognizing and enacting limits generates new patterns of valuation. 
Determinations that economic progress is no longer feasible invite discussions on how to valuate existing wealth (Fitzpatrick, 2004); determinations that human life is finite invite conversations on what value lives with different disabilities and conditions might hold; and determinations that a utopian future is unachievable require progressives to decide what parts of the present are worthy of struggling to preserve.

\section{Appendix: Congressional hearings on end-of-life care with witnesses sharing first-hand personal accounts of terminal disease}

"Death with Dignity: An Inquiry into Related Public Issues Part I-III," Hearings before the Special Committee on Aging, US Senate. 92nd Congress, 2nd Session. August 7-9, 1972.

"Moral, Ethical, and Legal Questions of Extraordinary Health Care, Hearing before the subcommittee on labor and public welfare, US Senate, 94th Congress, 1st Session. November 6, 1975.

"Alternatives to Institutionalization in the State of Washington," Hearing before the Select Committee on Aging, House of Representatives, 95th Congress, Second Session. June 19, 1978.

"Reauthorization of the Older Americans Act: 1981," Hearing Before the Subcommittee on Human Services of the Select Committee on Aging, House of Representatives 96th Congress, 2nd Session. October 15, 1980.

"The Hospice Alternative," Hearing Before the Special Committee on Aging, United States Senate, 97th Congress, 2nd Session. May 24, 1982.

“Administration's Proposed Payment System for Hospice Care." Hearing before the Committee on Aging, House of Representatives, 98th Congress, 1st Session. May 25, 1983.

"Medicare at the Crossroads," Hearing before the Subcommittee on Health and Long-Term Care of the Select Committee on Aging, House of Representatives, 98th Congress, 1st Session. June 13, 1983.

"Medicare Reform: The National and New Mexico Impact," Hearing Before the Committee on the Budget, United States Senate, 98th Congress, 2nd Session. February $15,1984$.

"Oversight on Federal Employees Health Benefits Program," Subcommittee on Compensation and Employee Benefits," House of Representatives 99th Congress, 1st Session. May 9, 1985.

"Dying with Dignity: Difficult Times, Difficult Choices," Hearing before the Select Committee on Aging, House of Representatives, 99th Congress, 1st Session, October $1,1985$.

"Catastrophic Health Insurance: The Tennessee Perspective," Hearing before the Subcommittee on Health and Long-Term Care of the Select Subcommittee on Aging, House of Representatives, 99th Congress, 2nd Session. March 27, 1986.

"Catastrophic and Long-Term Health Care," Hearings before the Committee on the Budget United States Senate, 100th Congress, 1st Session. November 11, 1987.

"Hospice and Respite Care," Hearing before the Special Committee on Aging, United States Senate. 101st Congress, 2nd Session. June 18, 1990. 
"Living Wills," Hearing before the Subcommittee on Medicare and Long-Term Care, Committee on Finance, US Senate, 101st congress, 2nd session. July 20, 1990.

"Planning for Your Golden Years," Hearing before the Select Committee on Aging, House of Representatives, 101st, 2nd session. July 28, 1990.

"Lethal Drug Abuse Prevention Act of 1998," Hearing before the Subcommittee on the Constitute of the Committee on the Judiciary House of Representatives, 105th Congress, 2nd Session. July 14, 1998.

"Exploring a Right to Try for Terminally Ill Patients," Hearing before the Committee on Homeland Security and Government Affairs, US Senate. September 22, 2016.

Acknowledgements I thank Theory and Society reviewers, Ashley Bates, Neil Fligstein, Marion Fourcade, Jeff Guhin, Katie Hauschildt, Rob Jansen, Barbara Kiviat, Carly Knight, Greta Krippner, Omar Lizardo, Santiago Molina, Tom Pessah, Sarah Quinn, Mary Shi, and Stefan Timmermans for comments on earlier drafts. I also greatly benefited from conversations with Renée Anspach, Steven Lukes, Fabian Pfeffer, Dylan Riley, and Yuval Yonay. Special thanks to Greta Krippner, who twice saved the manuscript from abandonment to the gnawing criticism of the mice. Previous versions were presented at the Morals and Markets Workshop (MIT, 2019); the American Sociological Association conference in New York (2019); Berkeley's Center for Culture, Organizations, and Politics; and UCLA Sociology Department's Health Working Group. I thank all participants who read and offered insight.

Funding This research was supported by grants from the University of California at Berkeley, University of Michigan, and the Charlotte Newcombe Foundation.

\section{Declarations}

Conflict of interest The author is unaware of any conflict of interest related to this research.

\section{References}

Abbott, A. (2014). The problem of excess. Sociological Theory, 32(1), 1-26.

Abend, G. (2014). 1. The Moral Background. In The moral background. Princeton University Press.

AHA [American Humanist Association]. (1973). Humanist Manifesto II. https://americanhumanist.org/whatis-humanism/manifesto2/

Aldridge, M. D., \& Kelley, A. S. (2015). The myth regarding the high cost of end-of-life care. American Journal of Public Health, 105(12), 2411-2415.

Almeling, R. (2007). Selling genes, selling gender: Egg agencies, sperm banks, and the MEdical market in genetic material. American Sociological Review, 72(3), 319-340.

Almeling, R. (2011). Sex cells: The medical market for eggs and sperm. University of California Press.

Anspach, R. (1993). Deciding who lives: Fateful choices in the intensive-care nursery. University of California Press.

Anteby, M. (2010). Markets, morals, and practices of trade: Jurisdictional disputes in the US commerce in Cadavres. Administrative Science Quarterly, 55(4), 606-638.

Appadurai, A. (1986). The social life of things: Commodities in Cultural Perspective. Cambridge University Press.

Arendt, H. (1958). The human condition. University of Chicago Press.

Arney, W. R., \& Bergen, B. J. (1984). Medicine and the Management of Living: Taming the last great beast. University of Chicago Press.

Ashmore, M., Mulkay, M. J., \& Pinch, T. (1989). Health and efficiency: A sociology of health economics. Open University Press.

Bandelj, N. (2020). Relational work in the economy. Annual Review of Sociology, 46, 251-272.

Barnard, A. (2016). Freegans: Diving into the wealth of food waste in America. University of Minnesota Press. 
Baszanger, I. (2012). One more chemo or one too many? Defining the limits of treatment and innovation in medical oncology. Social Science and Medicine, 75, 864-872.

Beckert, J., \& Aspers, P. (2011). Value in Markets. In J. Beckert \& P. Aspers (Eds.), The worth of goods: Valuation and pricing in the economy (pp. 3-38). Oxford University Press.

Bell, T. (1961). In the midst of life. Atheneum.

Beresford, L. (2007). The legacy of the Medicare hospice benefit. Newsline, 18(3), 8-16.

Berman, E. P. (2014). Not just neoliberalism: Economization in U.S. science and technology policy. Science, Technology, and Human Values, 39(3), 397-431.

Berman, M. (1988). All that is solid melts into air. Penguin.

Billnitzer, H. (1980). It's Your Death... Make the Most of It! : Morse Press.

Boltanski, L., \& Thévenot, L. (1999). On justification: Economies of worth. Princeton University Press.

Bourdieu, P. (1979). Symbolic Power. Critique of Anthropology, 4(13-14), 77-85.

Broom, A. (2015). Dying: A social perspective on the end of life. Ashgate.

Buck, J. (2005). Rights of passage: Reforming care of the dying, 1965-1986. Ph.d Dissertation, University of Virginia, Charlottesville, VA.

Bunker, J. P. (1970). Surgical manpower: A comparison of operations and surgeons in the United States and in England and Wales. New England Journal of Medicine, 282, 135-144.

Bush, V. (1945). Science: The Endless Frontier (report to the president). United States Government Printing Office.

Byock, I. R., \& Merriman, M. P. (1998). Measuring quality of life for patients with terminal illness: The Missoula-VITAS quality of life index. Journal of Palliative Medicine, 12, 231-244.

Çalişkan, K., \& Callon, M. (2009). Economization, part 1: Shifting attention from the economy towards processes of economization. Economy and Society, 38(3), 369-398.

Çalişkan, K., \& Callon, M. (2010). Economization, part 2: A research Programme for the study of markets. Economy and Society, 39(1), 1-32.

Callahan, D. (1987). Setting limits: Medical goals in an aging society. Simon \& Schuster.

Callahan, D. (2009). Taming the beloved beast: How medical technologies costs are destroying our health care system. Princeton University Press.

Chambliss, D. F. (1996). Beyond caring: Hospitals, nurses and the social Organization of Ethics. University of Chicago Press.

Chan, C. S.-C. (2009). Creating a market in the presence of cultural resistance. Theory and Society, 38(3), 271-305.

Chan, C. S.-C. (2012). Marketing death: Culture and the making of life insurance market in China. Oxford University Press.

Chetty, R., Grusky, D., Hell, M., Hendren, N., Manduca, R., \& Narang, J. (2017). The fading American dream: Trends in absolute income mobility since 1940. Science, 356(6336), 398-406.

Christin, A. (2018). Counting clicks: Quantification and variation in web journalism in the United States and France. American Journal of Sociology, 123(5), 1382-1415.

Civetta, J. M. (1973). The inverse relationship between cost and survival. Journal of Surgical Research, 14, 265-269.

Clark, D. (2013). Transforming the culture of dying: The work of the project on death in America. Oxford University Press.

General, C. (1979). Hospice care, a growing concept in the United States: Report to congress. U.S. General Accounting Office.

Constanza, R., Kubiszewski, I., Ragnarsdóttir, K. V., Roberts, D., De Vogli, R., \& Wilkinson, R. (2014). Development: Time to leave GDP behind. Nature News, 505(7483), 283-285.

Cullen, D. J., Ferrara, L. C., Briggs, B. A., Walker, P. F., \& Gilbert, J. (1976). Survival, hospitalization charges and follow-up results in critically ill patients. New England Journal of Medicine, 294(18), 982-987.

D’Alisa, G., Demaria, F., \& Kallis, G. (Eds.). (2015). Degrowth: A vocabulary for a new era. Routledge.

De Long, B. J. (1998). Estimates of world GDP, one million BC - Present. https://delong.typepad.com/print/ 20061012_LRWGDP.pdf [Last Accessed: May 13, 2021].

Dubos, R. (1959). The mirage of health: Utopias, Progress, and biological change. Rutgers University Press.

Durkheim, É. (1984). The division of labor in society. Basic Books.

Durkheim, É. (1995). The elementary forms of religious life. Free Press.

Dworkin, R. (1993). Life's dominion: An argument about abortion, euthanasia, and individual freedom. Vintage Books.

Ehrlich, P. R. (1968). The population bomb. Ballantine Books.

Einav, L., Finkelstein, A., Mullainathan, S., \& Obermeyer, Z. (2018). Predictive modeling of U.S. healthcare spending in late life. Science, 29(360), 1462-1465. 
Elliott, R. (2013). The taste for green: The possibilities and dynamics of status differentiation through "green" consumption. Poetics, 41(3), 294-322.

Elliott, R. (2018). The sociology of climate change as a sociology of loss. European Journal of Sociology, 59(3), 301-337.

Emanuel, E. J., \& Emanuel, L. (1994). The economics of dying: The illusion of cost saving at the end of life. New England Journal of Medicine, 330(8), 540-544.

Espeland, W., \& Sauder, M. (2007). Ranking and reactivity: How public measures recreate social worlds. American Journal of Sociology, 113(1), 1-40.

Espeland, W., \& Sauder, M. (2016). Engines of Anxiety: Academic ranking, reputations, and accountability. Russell Sage Foundation.

Evans, J. H. (2002). Playing god? Human genetic engineering and the rationalization of public bioethical debate. University of Chicago Press.

Eyal, G., Oncular, E., Oren, N., \& Rossi, N. (2010). The autism matrix: The social origins of the autism epidemic. Polity Press.

Filene, P. (1998). In the arms of others: A culture history of the right-to-die movement in America. Dee.

Fisher, W. F., \& Ponniah, T. (Eds.). (2015). Another world is possible: World social forum proposals for an alternative globalization. University of Chicago Press.

Fitzpatrick, T. (2004). A post-Productivist future for social democracy? Social Policy and Society, 3(3), 213222.

Folbre, N. (1991). The unproductive housewife: Her evolution in nineteenth-century economic thought. Signs, $16(3), 463-484$

Folbre, N. (2001). The invisible heart: Economics and family values. New Press.

Fontaine, L. (2014). The moral economy: Poverty, credit, and Trust in Early Modern Europe. Cambridge University Press.

Foucault, M. (2005). The hermeneutics of the subject. Picador.

Foucault, M. (2008). The birth of biopolitics. Palgrave MacMillan.

Fourcade, M. (2011). Cents and Sensibility: Economic Valuation and the Nature of "Nature". American Journal of Sociology, 116(6), 1721-1777.

Fourcade, M., \& Healy, K. (2013). Classification situations: Life-chances in the neoliberal era. Accounting, Organizations and Society, 38(8), 559-572.

Fourcade, M., \& Healy, K. (2016). Seeing Like a Market. Socio-Economic Review, 15(1), 9-29.

Fox, J. (2010). The hidden role of cost: Medicare decisions, transparency, and public trust. University of Cincinnati Law Review, 79, 1-51.

Fox, R. C., \& Swazey, J. (2008). Observing bioethics. Oxford University Press.

Freidson, E. (1970). Profession of medicine: A study of the sociology of applied knowledge. Harper \& Row.

Friedman, L. M. (1990). The republic of choice: Law, authority, and culture. Harvard University Press.

Fulton, R. (1977). Death, grief, and bereavement: A bibliography, 1845-1975. Arno Press.

Fulton, R. (1981). Death, grief, and Breavement II: A bibliography. Arno Press.

Galbraith, J. K. (1958). The affluent society. The Riverside Press Cambridge.

Golodetz, A. (Ed.). (1997). Vermont voices on Care of the Dying: A report from the Journey's end project of the Vermont ethics network. Vermont Ethics Network.

Gong, N. (2017). That proves You're mad, because you know it not: Impaired insight and the dilemma of governing psychiatric patients as legal subjects. Theory and Society, 46(3), 201-228.

Gong, N. (2019). Mind and Matter: Madness and Inequality in Los Angeles (Ph.D dissertation). University of California at Los Angeles, Los Angeles.

Gordon, R. (2016). The rise and fall of American growth: The U.S. standard of living since the civil war. Princeton University Press.

Graeber, D. (2002). Toward and anthropological theory of value. Palgrave.

Granovetter, M. (1985). Economic action and social structure: The problem of embeddedness. American Journal of Sociology, 91(3), 481-510.

Granovetter, M. (1990). The old and the new economic sociology. In R. Friedland \& A. F. Robertson (Eds.), Beyond the marketplace: Rethinking economy and society (pp. 89-112). Adeline.

Granovetter, M. (2017). Society and economy: Framework and principles. Harvard University Press.

Granovetter, M., \& Swedberg, R. (2011). Introduction to the third edition. In The Sociology of Economic Life (3rd ed., pp. xiii-xxx). Boulder, co.: Westview Press.

Griffen, Z., \& Panofsky, A. (forthcoming). Ambivalent economizations: The case of value added Moderling in teacher evaluations. Theory and Society.

Hacker, J. (2002). The divided welfare state: The battle over public and private social benefits in the United States. Cambridge University Press. 
Hanlan, A. J. (1979). Autobiography of dying. Doubleday.

Hauschildt, K. E. (2020). Whose Good Death? Understanding Inequality and the End of Life (Ph.D dissertation). University of Michigan, Ann Arbor, MI.

Hauser, R. (n.d.). The Wisconsin Longtitudinal Study. https://www.wisls.info/index.htm

Hegel, G. W. F. (1997). Reason in history. Prentice Hall.

Heimer, C. A., \& Staffen, L. R. (1998). For the sake of the children: The social Organization of Responsibility in the hospital and the home. University of Chicago Press.

Herhold, R. M. (1976). Learning to die, learning to live. Fortress Press.

Hirsch, F. (1978). Social limits to growth. Routledge and Paul Kegan.

Hospice Project Task Force. (1980). Report to the 1980 California legislature on the hospice project. California State Department of Public Health.

IoM [Institute of Medicine]. (1997). Approaching death: Improving Care at the end of life. National Academic Press.

IPCC [Intergovernmental Panel on Climate Change]. (2018). Special Report: Global Warming of 1.5 Degrees C. https://www.ipcc.ch/sr15/

Jevons, S. (1866). The coal question: An inquiry concerning the Progress of the nation, and the probable exhaustion of our coal mines. MacMillan.

Jonsen, A. (1998). The birth of bioethics. Oxford University Press.

Kameo, N. (2015). Gifts, donations, and loose coupling: Response to changes in academic entrepreneurship among bioscientists in Japan. Theory and Society, 44, 177-198.

Kant, I. (1996). An answer to the question: What is enlightenment. Penguin.

Karpik, L. (2010). Valuing the unique: The economics of singularities. Princeton University Press.

Katz, R. (1984). The silent world of doctor and patient. Johns Hopkins University Press.

Kaufman, S. (2015). Ordinary medicine: Extraordinary treatments, longer lives, and where to draw the line. Duke University Press.

Keleman, S. (1975). Living your dying. Random House.

Kiviat, B. (2019). The moral limits of predictive practices: The case of credit-based insurance scores. American Sociological Review, 84(6), 1134-1158.

Kojève, A. (1969). Introduction to the Reading of Hegel: Lectures on the phenomenology of Spirit. Basic Books.

Krippner, G. R. (2001). The elusive market: Embeddedness and the paradigm of economic sociology. Theory and Society, 30(6), 775-810.

Krippner, G. R. (2017). Democracy of credit: Ownership and the politics of credit access in late twentiethcentury America. American Journal of Sociology, 123(1), 1-47.

Krippner, G. R., \& Alvarez, A. S. (2007). Embeddedness and the intellectual projects of economic sociology. Annual Review of Sociology, 33, 219-240.

Kubler-Ross, E. (1969). On death and dying: What the dying have to teach doctors, nurses, clergy, and their own families. Scribner.

Kutscher, A. H. (1969). A bibliography of books on death, bereavement, loss, and grief: 1935-1968. Health Sciences.

Kutscher, A. H. (1974). A Bibilography of books on death, bereavement, loss, and grief: Supplement, 19681972. MSS Information.

Kutscher, M. (1975). A comprehensive bibliography of the thanatology literature. MSS Information.

Lahire, B. (2011). The plural actor. Polity Press.

Lainer-Vos, D. (2012). Manufacturing National Attachments: Gift-giving, market exchange, and the construction of Irish and Zionist diaspora bonds. Theory and Society, 41, 1-32.

Lam, D. (2011). How the world survived the population bomb: Lessons from 50 years of extraordinary demographic history. Demography, 48(4), 1231-1261.

Lambek, M. (2015). Living as if it mattered. In M. Lambek, V. Das, D. Fassin, \& W. Keane (Eds.), Four lectures in ethics: Anthropological perspectives (pp. 5-52). Hau Books.

Lamont, M. (2012). Toward a comparative sociology of valuation and evaluation. Annual Review of Sociology, 38, 201-221.

Lavi, S. J. (2005). The modern art of dying: A history of euthanasia in the United States. Princeton University Press.

Livne, R. (2014). Economies of dying: The moralization of economic scarcity in U.S. hospice care. American Sociological Review, 79(5), 888-911.

Livne, R. (2019). Values at the end of life: The logic of palliative care. Harvard University Press.

Lubitz, J., \& Riley, G. (1993). Trends in Medicare payments in the last year of life. New England Journal of Medicine, 328, 1092-1096. 
Lukes, S. (2005). Power: A radical view. Palgrave MacMillan.

MacKenzie, D. (2013). Visible, tradable carbon: How emissions markets are constructed. In P. Quattrone, N. Thrift, C. McLean, \& F. Regis Puyou (Eds.), Imagining organizations. Routledge.

Malthus, T. R. (1985). An essay on the principle of population. Penguin.

Mannes, M. (1974). Last rights. William Morrow.

Marx, K. (1964). Economic and philosophic manuscripts of 1844. International Publishers.

Marx, K. (1976). Capital Vol. I. Penguin.

McAdam, D. (1996). Conceptual origins, current problems, future directions. In Comparative perspectives on social movements: Political opportunities, mobilizing structures, and cultural framings (pp. 23-40). Cambridge University Press.

McCoy, M. C. (1974). To die with style! Abingdon Press.

MDP [Missoula Demonstration Project]. (2004). Life's End Institute. https://web.archive.org/web/ 20040806185836/http://www.lifes-end.org/index.phtml

MDP [Missoula Demonstration Project]. (2013). MDP Mission. http://www.webarchive.org.web/ 20130713043510/http://www.dyingwell.org/MDP.htm

MDP [Missoula Demonstration Project]. (n.d.). The Missoula-VITAS Quality of Life Index (MVQOLI): Guide to Using the MVQOLI. http://www.npcrc.org/files/news/missoula_vitas_quality_of_life_index.pdf

Meadows, D. H., Meadows, D. L., Randers, J., \& Beherns, W. W. (1971). The limits to growth: A report for the Club of Rome's project on the predicament of mankind. Universe Books.

Miller, A. J., \& Acri, M. J. (1977). Death: A bibliographical guide. Scarecrow Press.

Mitchell, T. (2002). The rule of experts: Egypt, techno-politics, modernity. University of California Press.

Mitford, J. (1963). The American way of death. Simon \& Schuster.

Mor, V., \& Barnbaum, H. (1983). Medicare legislation for hospice care: Implications of national hospice study data. Health Affairs, 2(2), 80-90.

Neumann, P. J., \& Chambers, J. D. (2012). Medicare's enduring struggle to define "reasonable and necessary" care. New England Journal of Medicine, 367, 1775-1777.

NHPCO [National Hospice and Palliative Care Association]. (2012). Facts and figures (2012). National Hospice and Palliative Care Association. https://www.nhpco.org

Notzon, F. C., Placek, P. J., \& Taffel, S. M. (1987). Comparisons of National Cesarean-Section Rates. New England Journal of Medicine, 316, 386-389.

Offe, C. (2019). What, if anything, might we mean by "progressive" politics today? In Augewählte, Schriften von Clause Offe (pp. 241-251). Springer.

Ortner, S. (2003). New Jersey dreaming: Capital, culture, and the class of '58. Duke University Press.

OSI [Open Society Institute]. (2004). Transforming the culture of dying: The project on death in America. Open Society Institute.

Osterweis, M., \& Szmuszkoviz Champagne, D. (1978). U.S. hospice movement: Issues in development. American Journal of Public Health, 69(5), 492-496.

Pantilat, S. Z., Rabow, M. W., Kerr, K. M., \& Markowitz, A. J. (2007). Palliative Care in California: The business case for hospital-based programs. California Healthcare Foundation.

Parsons, T. (1951). The social system. Free Press.

Patrizi, P., Thompson, E., \& Spector, A. (2011). Improving Care at the end of life how the Robert Wood Johnson Foundation and its grantees built the field. Robert Wood Johnson Foundation.

Payer, L. (1988). Medicine and culture. Henry Holt \& Co..

Pew Research Center (2013). Views on End-of-Life Medical Treatments.

Piketty, T. (2014). Capital in the Twenty-First Century. Harvard University Press.

Piro, P. A., \& Lutins, T. (1973). Utilization and reimbursement under Medicare for 1967 and 1968 decedents. Social Security Bulletin, 74(11702).

Polanyi, K. (1977). The livelihood of man. Academic Press.

Polanyi, K. (1992). The economy as an institute process. In M. Granovetter \& R. Swedberg (Eds.), The sociology of economic life (pp. 29-52). Westview Press.

Polanyi, K. (2001). The great transformation. Beacon Press.

Portes, A. (1994). The informal economy and its paradoxes. Princeton University Press.

Poteet, G. H. (1976). Death and dying: A bibliography, 1950-1974. Whitston.

Quinn, S. (2008). The transformation of morals in markets: Death, benefits, and the exchange of life insurance policies. American Journal of Sociology, 114(3), 738-780.

Relmand, A. (1980). The new medical-industrial complex. New England Journal of Medicine, 303(17), 962970 .

Rid, A. (2014). Will a patient preference predictor improve treatment decision making for incapacitated patients? Journal of Medicine and Philosophy, 39, 99-103. 
Rid, A., \& Wendler, D. (2014a). Use of a PAtient preference predictor to help make medical decisions for incapacitated patients. Journal of Medicine and Philosophy, 39, 104-129.

Rid, A., \& Wendler, D. (2014b). The treatment decision making for incapacitated patients: Is development and use of a patient preference predictor feasible? Journal of Medicine and Philosophy, 39, 130-152.

Riley, G., \& Lubitz, J. (2010). Long-term trends in Medicare payment in the last year of life. Health Services Research, 45, 565-576.

Robinson, J. N. (2020). Making markets on the margins: Housing finance agencies and the racial politics of credit expansion. American Journal of Sociology, 125(4), 974-1029.

Rockström, J., Steffen, W. K., Noone, K., Persson, Å., \& Chapin, F. S. (2009). Planetary boundaries: Exploring the safe operating space for humanity. Ecology and Society, 14(2), 32-55.

Rosenberg, C. E. (1987). The Care of Strangers: The rise of America's hospital system. Basic Books.

Rosenthal, E. (2017). An American sickness: How healthcare became big business and how you can take it Back. Penguin.

Saunders, C. (1969). The moment of truth: Care of the Dying Person. In L. Pearson (Ed.), Death and dying: Current issues in the treatment of the dying person (pp. 49-78). Case Western Reserve University.

Scitovsky, A. A. (1984). The high cost of dying': What do the data show? Milbank Memorial Fund Quarterly / Health and Society, 62(4), 591-608.

Scitovsky, A. A. (1988). Medical Care in the Last Twelve Months of life: The relation between age, Funcitonal status, and medical care expenditures. Milbank Quarterly, 66, 640-660.

Scott Bermer, M. (1979). And send the sun tomorrow: A journal of my Father's last days. Winston Press.

Scott, J. C. (1976). The moral economy of the peasant: Rebellion and subsistence in Southeast Asia. Yale University Press.

Sell, I. L. (1977). Dying and death: An annotated bibliography. Tiresias Press.

Shapiro, S. (2019). Speaking for the dying: Life-and-death decisions in the intensive care unit. University of Chicago Press.

Siebold, C. (1992). The hospice movement: Easing Death's pains. Twayne.

Simon, J. L. (1996). The ultimate resource. Princeton University Press.

Simpson, M. A. (1979). Dying, death, and grief. Plenum.

Simpson, M. A. (1987). Dying, death, and grief: A critical bibliography. University of Pittsburgh Press.

Singer, P. (2009). 15. Why We Must Ration Health Care.

Slaboch, M. W. (2017). A road to nowhere: The idea of Progress and its critics. University of Pennsylvania Press.

Smith, B. (1969). Dear gift of life: A Man's encounter with death. Pendle Hill.

Sontag, S. (1978). Illness as metaphor. Farrar, Straus \& Giroux.

Stark, D. (2000). For a Sociology of Worth. In Keynote Address, Annual Conference of the European Association of Evolutionary Political Economy (Vol. 3). Berlin.

Starr, P. (1982). The social transformation of American medicine. Basic Books.

Steinhauser, K. E., Christakis, N., Clipp, E. C., McNeilly, M., McIntyre, L., \& Tulsky, J. A. (2000). Factors considered important at the end of life by patients, family, physicians, and other care providers. Journal of the American Medical Association, 284, 2476-2482.

Stevens, R. (1989). In sickness and in wealth: American Hopsitals in the twentieth century. Basic Books.

Sudnow, D. (1967). Passing on. Prentice-Hall.

Taylor, K.-Y. (2019). Race for profit: How banks and the real estate industry undermined black homeownership. Chapel Hill: University of North Carolina.

Thompson, E. P. (1971). The moral economy of the English crowd. Past and Present, 50, 76-136.

Timmermans, S. (2005). Death brokering: Constructing culturally appropriate deaths. Sociology of Health and Illness, 27(7), 993-1013.

Turner, F. J. (2008). The significance of the frontier in American history. Penguin.

Ubel, P. (2000). Pricing life: Why It's time for health care rationing. MIT Press.

Warner, E., \& Gualtieri-Reed, T. (2014). Improving Care for People with serious illness through innovative Payer-provider partnership. Center to Advance Palliative Care (CAPC).

Weber, M. (2011). The Protestant ethic and the Spirit of capitalism. Oxford University Press.

Werth, J. L., \& Blevins, D. (2002). Public policy and end-of-life care. American Behavioral Scientist, 46(3), $401-417$.

West, J. (1966). A matter of time. Avon.

West, J. (1976). The woman said yes: Encounters with life and death. Harcourt Brace Jovanovich.

Wherry, F. F. (2011). The Philadelphia barrio: The arts, branding, and neighborhood transformation. University of Chicago Press.

Worcester, A. (1961). The Care of the Aged, the dying, and the dead. Charles Thomas. 
Wright, E. O. (2010). Envisioning real utopias. Verso.

Zaloom, C. (2019). Indebted: How families make college work at any cost. Princeton University Press.

Zelizer, V. A. (1979). Morals and markets: The development of life Insurance in the United States. Transaction.

Zelizer, V. A. (1985). Pricing the priceless child: The changing social value of children. Basic Books.

Zelizer, V. A. (1994). The social meaning of money. Basic Books.

Zelizer, V. A. (2004a). The purchase of intimacy. Princeton University Press.

Zelizer, V. A. (2004b). Circuits of commerce. In J. C. Alexander, G. T. Marx, \& C. L. Williams (Eds.), Self, social structure, and beliefs: Explorations in sociology (pp. 122-144). University of California Press.

Zelizer, V. A. (2011). Economic lives: How culture shapes the economy. Princeton University Press.

Zelizer, V. A. (2012). How I became a relational economic sociologist and what does it mean? Politics and Society, 40(2), 145-174.

Publisher's note Springer Nature remains neutral with regard to jurisdictional claims in published maps and institutional affiliations.

Roi Livne is an Assistant Professor of Sociology at the University of Michigan. His book, Values at the End of Life: The Logic of Palliative Care, on which parts of this paper draw, was published by Harvard University Press in 2019. He is currently writing on finitude, economization, and the sociology of pricing in US hospitals. 